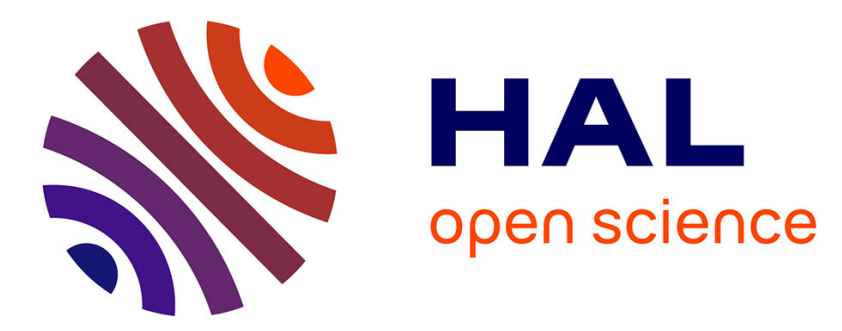

\title{
3D morphometry of valley networks on Mars from HRSC/MEX DEMs: Implications for climatic evolution through time
}

\author{
V. Ansan, N. Mangold
}

\section{- To cite this version:}

V. Ansan, N. Mangold. 3D morphometry of valley networks on Mars from HRSC/MEX DEMs: Implications for climatic evolution through time. Journal of Geophysical Research. Planets, 2013, 118 (9), pp.1873-1894. 10.1002/jgre.20117 . hal-02305935

\section{HAL Id: hal-02305935 \\ https://hal.science/hal-02305935}

Submitted on 4 Oct 2019

HAL is a multi-disciplinary open access archive for the deposit and dissemination of scientific research documents, whether they are published or not. The documents may come from teaching and research institutions in France or abroad, or from public or private research centers.
L'archive ouverte pluridisciplinaire HAL, est destinée au dépôt et à la diffusion de documents scientifiques de niveau recherche, publiés ou non, émanant des établissements d'enseignement et de recherche français ou étrangers, des laboratoires publics ou privés. 


\title{
3D morphometry of valley networks on Mars from HRSC/MEX DEMs: Implications for climatic evolution through time
}

\author{
V. Ansan ${ }^{1}$ and N. Mangold ${ }^{1}$ \\ Received 19 January 2013; revised 24 July 2013; accepted 1 August 2013.
}

[1] Martian valley networks have been identified mainly in the Noachian heavily cratered uplands. Eight dense branching valley networks were studied in Noachian terrains of Huygens, Newcomb and Kepler craters, south Tyrrhena Terra, and Thaumasia, in Hesperian terrains of Echus Plateau and west Eberswalde craters, and in Amazonian terrains of Alba Patera, using images and digital elevation models from the Mars Express High Resolution Stereo Camera to determine 2D and 3D morphometric parameters. Extracted geomorphic parameters show similar geometry to terrestrial valleys: drainage densities, organization from bifurcation ratios and lengths ratios, Hack exponent consistent with terrestrial values of $\sim 0.6$, and progressive deepening of valleys with increasing Strahler order. In addition, statistics on valley depths indicate a deeper incision of Noachian valleys compared to younger post-Noachian valleys ( $<25 \mathrm{~m}$ for Amazonian ones compared to $>100 \mathrm{~m}$ for Noachian ones), showing a strong difference in fluvial erosion. These characteristics show that dense Martian valley networks formed by overland flows in relation to a global atmospheric water cycle in Noachian epoch and confirm that the later stages of activity may be related to shorter duration of activity, distinct climatic conditions, and/or regional processes, or conditions.

Citation: Ansan, V., and N. Mangold (2013), 3D morphometry of valley networks on Mars from HRSC/MEX DEMs: Implications for climatic evolution through time, J. Geophys. Res. Planets, 118, doi:10.1002/jgre.20117.

\section{Introduction}

[2] Valley networks on Mars have been the subject of considerable debate concerning their formation processes and their implications for the Martian climate. A variety of erosive processes by liquid water has been suggested, including fluvial erosion exclusively [e.g., Malin and Carr, 1999; Carr and Malin, 2000], groundwater sapping exclusively resulting from geothermal or hydrothermal heating [e.g., Sharp and Malin, 1975; Pieri, 1976, 1980; Howard, 1988; Squyres, 1989; Baker, 1990; Gulick, 1998, 2001; Goldspiel and Squyres, 2000; Luo, 2002], and a combination of surface runoff and groundwater sapping [e.g., Milton, 1973; Baker and Kochel, 1979; Gulick and Baker, 1989, 1990; Baker et al., 1992; Carr, 1995, 1996; Grant, 2000; Malin and Edgett, 2000]. Data from Mars Orbiter LASER Altimeter (MOLA) [Smith et al., 1999] show that branching valley networks were incised by fluids that followed surface topography [e.g., Williams and Phillips, 2001; Craddock and Howard, 2002; Ansan and Mangold, 2006]. Recent studies suggested that precipitation, either as snowmelt or rainfall,

\footnotetext{
${ }^{1}$ Laboratoire de Planétologie et Géodynamique de Nantes, LPGNantesUMR CNRS 6112, Nantes, CEDEX 3, France.

Corresponding author: V. Ansan, Laboratoire de Planétologie et Géodynamique de Nantes, LPGNantes-UMR CNRS 6112, 2 rue de la Houssinière, BP 92208, FR-44322 Nantes CEDEX 3, France.

(veronique.ansan@univ-nantes.fr)

(C)2013. American Geophysical Union. All Rights Reserved. 2169-9097/13/10.1002/jgre.20117
}

was necessary to create at least some of the valleys [e.g., Craddock and Howard, 2002; Howard et al., 2005; Irwin et al., 2005a; Ansan and Mangold, 2006; Ansan et al., 2008; Mangold et al., 2008; Hynek et al., 2010; AndrewsHanna and Lewis, 2011]. Formation by liquid water would imply that Mars had a warmer and wetter climate early in its history [Sagan et al., 1973; Carr, 1981; Forget and Pierrehumbert, 1997; Craddock and Howard, 2002; Howard et al., 2005; Irwin et al., 2005b] because liquid water is unstable on the Martian surface under the present-day climate [Leighton et al., 1965; Farmer and Doms, 1979]. Nevertheless, present climate models have not been able to reach the conditions necessary for these processes to have occurred perennially, in the past [e.g., Kasting, 1991; Clifford, 1993; Fastook et al., 2012]; thus, questioning the formation mechanism of these landforms, i.e., whether they could form under a cold climate in association with endogenic or exogenic processes (volcanism or impacts, [e.g., Fassett and Head, 2007; Toon et al., 2010; Mangold et al., 2012a; Mangold, 2012]).

[3] Since visible images first acquired by Viking orbiter in 1976, we have known that valley networks occur in the heavily cratered upland of the Noachian age (>3.6 Gyr) [e.g., Mars Channel Working Group, 1983; Carr, 1996, Carr and Chuang, 1997, Tanaka, 1986, Hartmann and Neukum, 2001; Hartmann, 2005]. Most valley networks date from the Late Noachian to the beginning of the Early Hesperian [e.g., Carr and Clow, 1981; Ansan and Mangold, 2006; Fassett and Head, 2008; Bouley et al., 2010; Hynek et al., 2010]. However, prolonged activity and/or reactivations 


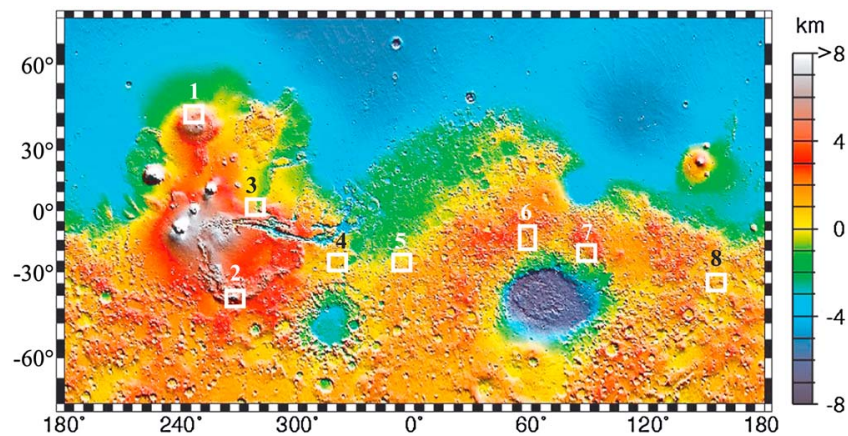

Figure 1. Location of valley networks studied shown on a MOLA topographic map. 1. Alba Patera, 2. Warrego Vallis in Thaumasia Highlands, 3. Valley networks in Echus Plateau, 4. Holden/Eberswalde crater, 5. Valley networks near Newcomb crater (North of Noachis Terra), 6. Huygens crater, 7. Vichada Valles in Tyrrhena Terra, and 8. Valley networks in Terra Cimmeria near Kepler crater.

of ancient valleys seem to have occurred well into the Hesperian [Baker and Partridge, 1986; Mangold and Ansan, 2006; Bouley et al., 2009; Bouley et al., 2010; Hynek et al., 2010]. In addition, Late Hesperian to Amazonian valley networks have been observed on volcanoes [Gulick and Baker, 1990; Hauber et al., 2005; Ivanov and Head, 2006; Ansan et al., 2009], Valles Marineris' interior and plateau [Mangold et al., 2004, 2008; Ansan et al., 2008; Quantin et al., 2005; Chapman et al., 2010; Weitz et al., 2010], and midlatitude ice-rich landforms [Fassett et al., 2010; Dickson et al., 2009]. The current view is that these late fluvial landforms may have formed under more localized conditions rather than a globally warmer climate [Fassett and Head, 2008, Mangold et al., 2008], but their existence adds complexity to the overall picture of fluvial activity and questions if the Noachian valleys did not form as well by localized environments with a denser spatial occurrence. The comparative morphology of Noachian and post-Noachian valleys has never been tested quantitatively.

[4] In order to contribute to these fundamental questions concerning the evolution of fluvial activity and its implications for past conditions, a quantitative study of the morphometry of fluvial valley networks was achieved by using high-resolution topography. MOLA altimetry data make it possible to study the geometry and topography of valley networks at spatial resolution of typically $\sim 500 \mathrm{~m}$ [e.g., Stepinski and Stepinski, 2005; Ansan and Mangold, 2006; Luo and Stepinski, 2006; Hynek et al., 2010], but this resolution is not sufficient to identify small tributaries. In contrast, Mars Express High Resolution Stereo Camera (HRSC) on board Mars Express [Neukum et al., 2004; Jaumann et al., 2007] acquires visual images with a typical spatial resolution of $\sim 10 \mathrm{~m}$ for nadir images, which provides a higher resolution, as well as the stereo capability and the broad coverage necessary to study watersheds. Each image covers a swap of $\sim 60 \mathrm{~km}$ width over few $100 \mathrm{~s} \mathrm{~km}$ of meridian length. To characterize these watersheds, we studied selected valley networks of various epochs using approximately the same magnitude of watershed area, i.e., few $\sim 100 \mathrm{~km}^{2}$ (Figure 1). We determined their 2D characteristics (e.g., length, basin area, drainage density, Strahler orders, bifurcation ratio, and length ratio) and 3D characteristics through Hack's law and valley depths measurements. This analysis provides a way to compare valleys of different epochs and evaluate the degree of incision as well as processes involved in their formation.

\section{Approach and Methods}

\subsection{Rationale for Valley Network Selection}

[5] At moderate image resolution such as that provided by the Viking spacecraft, the use of the term "valley network" was often imprecise. The distinction between different morphologic features was difficult, except for well-defined outflow channels (e.g., Ares vallis, Athabasca Vallis, etc.), but all other fluvial landforms were often treated under the same term of "valley networks." Actually, based on recent imagery at scales ranging from 0.5 to $100 \mathrm{~m}$, the valley networks may be classified in 2D plan view, in two main endmembers: (1) Dense branching valley networks with many tributaries (e.g., Warrego Vallis), and (2) valley networks dominated by a main wide valley and a poor number of tributaries (e.g., Nanedi Vallis or Nirgal Vallis) that do not look like terrestrial valley networks (Figure 2). The first group, characterized by branching valleys with a well-defined morphometry, will be the focus of our study. The second group may be related to a period with more intense groundwater seepage [Harrison and Grimm, 2008], or may be strongly influenced by the lithology of plateaus they incise [Mangold et al., 2008; Craddock et al., 2012]. The second group also contains several late stage wide valleys that display small delta-fans or step-deltas [e.g., Malin and Edgett, 2003; Howard et al., 2005; Mangold and Ansan, 2006; Kraal et al., 2008; Hauber et al., 2009]. Recent studies show that these valleys and deltas formed by the deposition of eroded material during a short-lived event [e.g., Kraal et al., 2008; Kleinhans et al., 2010]. The morphology of the latter is more difficult to treat as typical terrestrial-like valley networks, so their morphometry will not be considered in this study.

[6] Few of the first class of valley networks retained inner channels, because of subsequent dust/sand filling [e.g., Irwin et al., 2005a; Jaumann et al., 2005; Kleinhans, 2005]. Moreover, inner river channels are the remnant of the last episode of fluvial activity. Unfortunately, erosional products at the outlet of these valleys are not usually found because these deposits were subsequently eroded or resurfaced by volcanic deposits [e.g., Irwin et al., 2005a; Fassett and Head, 2008]. The lack of channels and terminal deposits prevents us from constraining an accurate hydrologic model of these valleys, therefore restricting us to morphometric analyses of the valley and watershed to constrain past fluvial activity.

[7] For this study, the selection of valley networks of different ages is based on (1) the same valley morphomology and branching organization, and (2) available HRSC data with a good spatial resolution, usually $<100$ m.pixel ${ }^{-1}$ (Figure 1). The only examples of dense early Amazonian valley networks are those present on younger Martian volcanoes (e.g., Alba Patera and Hecates Tholus) [Carr, 1995; Gulick and Baker, 1990; Fassett and Head, 2008]. Alba Patera was selected because it has been imaged by a large set of HRSC data [Ansan et al., AGU 2009]. Valley networks that are Late Hesperian in age were chosen at Echus Plateau [Mangold et al., 2004, 2008] and around Eberswalde crater [Mangold et al., 2012a]. Noachian valley networks are more widespread and were selected primarily by the quality of 

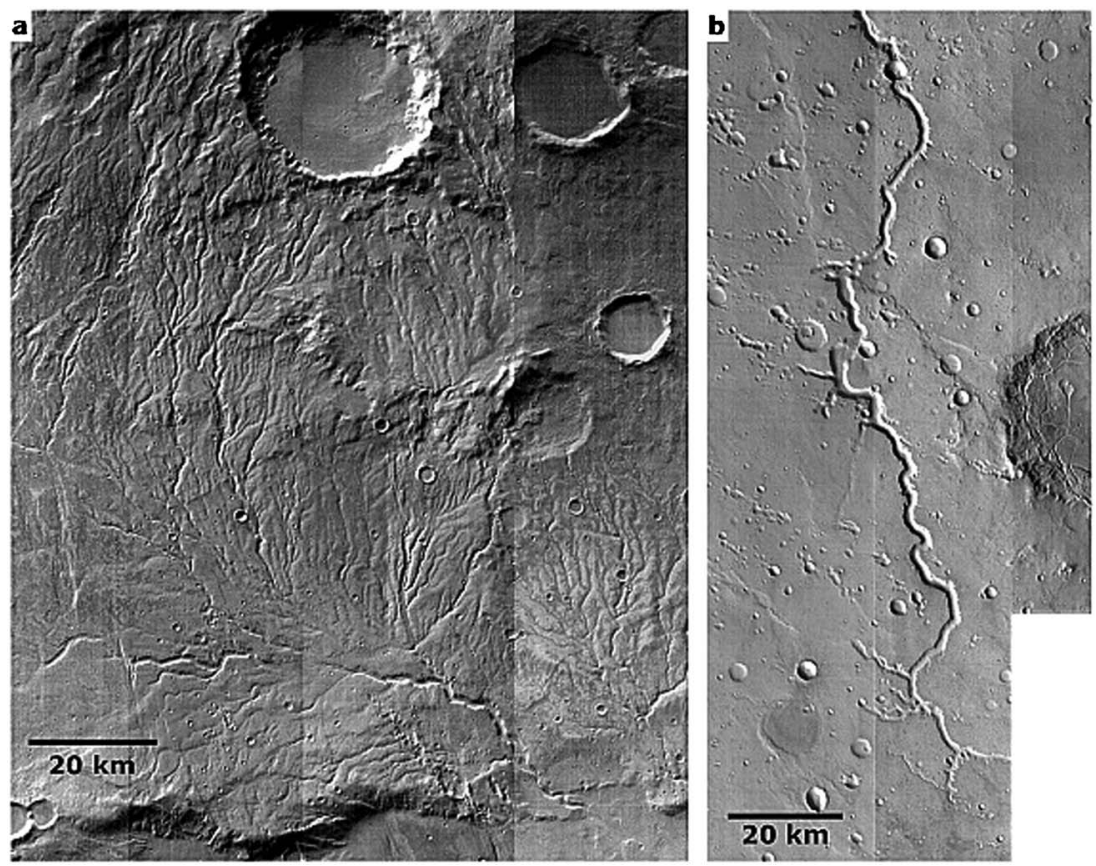

Figure 2. Comparative view between a dense valley network and a poorly branching valley network in THEMIS images $\left(100 \mathrm{~m}\right.$.pixel $\left.{ }^{-1}\right)$. (a) Warrego Valles on the southern boundary of the Thaumasia highlands. The drainage basin is densely dissected with many, well-developed tributaries, (b) Eastern Nanedi Vallis in Xanthe Terra: Tributaries and source regions are poorly developed.

HRSC data and the interest of the valleys, (i.e., several Noachian valley networks are partly flooded by subsequent lava flows or display large valleys of the second group). Regions where Noachian valley networks were selected include: east of Huygens crater, Terra Cimmeria, SW area of the Newcomb crater, Tyrrhena Terra (corresponding to Vichada Valles), and Thaumasia highlands (including Warrego Vallis). These examples allow us to explore the temporal evolution of valley networks morphometry while evaluating the processes involved in their formation.

\subsection{Data}

[8] The HRSC camera acquired images in five panchromatic channels under different observation angles, as well as four color channels at relatively high spatial resolution [Neukum et al., 2004]. In our work, we used only the panchromatic nadir image in which the spatial resolution reaches generally 10 to $50 \mathrm{~m}$ pixel $^{-1}$, and the two panchromatic stereoscopic images with a spatial resolution of similar range to four times lower than that of the nadir image. In addition, we used the latest image data set acquired after orbit $\# 5000$, primarily because of their good spatial coverage over the densely cratered terrains in the south hemisphere (see Table 1 for image parameters).

[9] The first step of HRSC image processing is orthorectification, producing level 2 images. Using the photogrammetric software developed both at the Deutsches Zentrum für Luft- and Raumfahrt (DLR) and the Technical University of Berlin [Scholten et al., 2005], we projected level 2 images onto a reference surface corresponding to the MOLA topography with a spatial grid of $5 \mathrm{~km} \mathrm{pixel}^{-1}$ [Smith et al., 1999], a sinusoidal projection at a given central meridian, and the best spatial resolution, taking into account the spacecraft position, the camera orientation along the ground track, and the camera characteristics included in exterior orientation data. The coordinates of ortho-rectified nadir images are defined in the planetocentric system of the Mars IAU 2000 ellipsoid [Seidelmann et al., 2002; Duxbury et al., 2002].

[10] In addition, we generate the HRSC digital elevation models (DEMs) from nadir and stereoscopic images, using the photogrammetric software developed at the DLR and the Technical University of Berlin [Scholten et al., 2005; Albertz et al., 2005; Gwinner et al., 2007]. The location of each homologous point is known with an accuracy of $<50 \mathrm{~m}$ [Ansan et al., 2008] and projected on the Mars IAU ellipsoid [Duxbury et al., 2002; Seidelmann et al., 2002]. The height is calculated taking into account the Martian geoid defined as the topographic reference for the Martian heights, i.e., the areoid [Smith, 1999].

[11] The choice of the DEM's cell size is influenced by the spatial distribution of 3D object points bounding the geological features. Given the heterogeneous distribution of these points in the DEM and the desire to accurately characterize the geologic features, we choose the smallest grid cell size that leaves $>70 \%$ of the cells filled. We take caution not to extract topographic information in areas devoid of points. The resolution of the resulting DEM is thus often two to three times smaller than that of the original image resolution. The calculated height accuracy is usually $20 \mathrm{~m}$ when geometric parameters of the HRSC camera, the terrain roughness, and the image quality are optimal. The individual DEM characteristics are compiled in Table 1, for each study area, with a mean spatial gridding of $75 \mathrm{~m} \cdot \mathrm{pixel}^{-1}$, except for small regions like Alba Patera and Terra Cimmeria where the best spatial gridding of $\sim 30$ m.pixel ${ }^{-1}$ is possible, and East Huygens crater with a possible spatial gridding of $250 \mathrm{~m} \cdot \mathrm{pixel}^{-1}$. 
Table 1. HRSC Images and DEM Characteristics ${ }^{\mathrm{a}}$

\begin{tabular}{|c|c|c|c|c|c|c|c|c|c|c|}
\hline \multirow[b]{2}{*}{ Region } & \multirow{2}{*}{$\begin{array}{c}\text { HRSC Image } \\
\text { Name }\end{array}$} & Nadir & Stereo \#1 & Stereo \#2 & HRSC DEM & \multirow[b]{2}{*}{ nbp } & \multirow{2}{*}{$\frac{\sigma \mathrm{x}}{\mathrm{m}}$} & \multirow{2}{*}{$\frac{\sigma y}{\mathrm{~m}}$} & \multirow{2}{*}{$\frac{\sigma \mathrm{z}}{\mathrm{m}}$} & \multirow{2}{*}{$\frac{\sigma \mathrm{h}}{\mathrm{m}}$} \\
\hline & & m/pixel & m/pixel & m/pixel & m/pixel & & & & & \\
\hline Alba Patera & h3515 & 13.9 & 14.8 & 14.9 & 30 & 5643723 & 3.4 & 8.5 & 8.1 & 6.2 \\
\hline Echus Plateau & h2204 & 16.7 & 33.9 & 38.9 & 50 & 2108364 & 19.0 & 53.9 & 17.2 & 53.4 \\
\hline Holden/Eberswalde & h4310 & 12.9 & 14.1 & 13.3 & 60 & 7995029 & 12.8 & 9.5 & 8 & 10.0 \\
\hline Crater & h7233 & 20.2 & 40.4 & 47.1 & 60 & 2601473 & 8.3 & 6.0 & 5.5 & 7.1 \\
\hline Thaumasia Highlands & h0453 & 17.6 & 35.0 & 69.2 & 80 & 2341913 & 6.7 & 16.9 & 14.9 & 12.8 \\
\hline (Warrego Vallis) & h0486 & 20.4 & 40.2 & 48.2 & 80 & 2654160 & 14.1 & 29.8 & 26.5 & 22.6 \\
\hline Tyrrhena Terra & h0528 & 57.4 & 102.2 & 172.7 & 100 & 6016033 & 25.7 & 58.6 & 39.9 & 49.3 \\
\hline \multirow[t]{7}{*}{ (Vichada Valles) } & h0561 & 79.8 & 135.8 & 301.8 & 180 & 763339 & 22.5 & 51.5 & 28.1 & 48.3 \\
\hline & h2096 & 12.3 & 25.6 & 27.0 & 75 & 3479919 & 7.6 & 23.6 & 12.9 & 21.5 \\
\hline & h2107 & 15.6 & 25.0 & 26.1 & 75 & 3304438 & 6.5 & 19.6 & 11.5 & 17.6 \\
\hline & h6498 & 29.3 & 38.6 & 56.5 & 150 & 1688348 & 8.1 & 21.5 & 13.8 & 18.9 \\
\hline & h6523 & 32.3 & 81.1 & 61.6 & 150 & 1187453 & 7.5 & 20.2 & 13.5 & 17.3 \\
\hline & ha541 & 16.8 & 37.7 & 34.3 & 75 & 1160951 & 6.1 & 19.3 & 7.5 & 18.9 \\
\hline & ha548 & 14.5 & 32.1 & 30.2 & 50 & 4489241 & 3.7 & 11.4 & 5.7 & 10.6 \\
\hline Mosaic mnt & & & & & 75 & & & & & \\
\hline \multirow[t]{4}{*}{ SW Newcomb crater } & h4328 & 11.9 & 25.0 & 25.6 & 75 & 1621886 & 15.8 & 5.9 & 13.4 & 12.8 \\
\hline & h6438 & 15.3 & 34.3 & 31.1 & 70 & 4644350 & 13.9 & 4.7 & 7.7 & 12.6 \\
\hline & h6456 & 16.3 & 36.8 & 32.8 & 75 & 3954920 & 15.7 & 6.1 & 9.1 & 14.5 \\
\hline & ha563 & 15.6 & 34.8 & 32.0 & 50 & 7310412 & 18.2 & 6.1 & 8.5 & 17.2 \\
\hline Mosaic mnt & & & & & 75 & & & & & \\
\hline \multirow[t]{2}{*}{ Cimmeria Terra } & h0228 & 21.7 & 22.6 & 23,6 & 22.4 & 5908769 & 14.5 & 5.6 & 9.4 & 13.0 \\
\hline & h0241 & 21.7 & 22.6 & 23,6 & 22.4 & 11817539 & 14.5 & 5.7 & 9.5 & 13.1 \\
\hline Mosaic mnt & & & & & 22.4 & & & & & \\
\hline East Huygens crater & h0532 & 37.6 & 70.0 & 98.7 & 250 & 2231328 & 19.2 & 28.1 & 17.4 & 23.1 \\
\hline
\end{tabular}

anbp: number of homologous points found to generate DEM. $\sigma \mathrm{x}, \sigma \mathrm{y}, \sigma \mathrm{z}$, and $\sigma \mathrm{h}$ : accuracy on the geocentric location of homologous points and on their height above areoid.

\subsection{Valley Networks Detection}

[12] For the study areas, the HRSC images and DEMs are included in a GIS database. Mosaics of individual DEMs were performed in order to map the altimetry of each area study. First, we manually mapped the valley networks from nadir images at $\sim 10$ m.pixel $^{-1}$ taking into account the geological context.

[13] We used a hydrologic analysis (DNR hydromod) included in ArcGIS software in order to extract the valley network from DEM mosaics. This analysis is derived from standard techniques used to extract terrestrial drainage networks from topographic data sets [e.g., O'Callaghan and Mark, 1984, Tarboton et al., 1989, 1991]. The program takes a DEM as an input and produces a number of consecutive grids of the same dimension as the original DEM as outputs. The DNR hydromod program consists of three steps of processing: (1) the original topography (DEM) is modified removing sinks to produce a continuous flow direction grid; (2) a flow direction grid is calculated from the center of cell to the steepest downslope direction of the eight neighboring cells (D8 algorithm); (3) a flow accumulation grid is generated as the cumulative number of cells flowing into each downslope cell. Cells that have high accumulation of flow may be used to identify stream channels.

[14] The first step is crucial in order to make the original topography drainable, creating a depressionless DEM by allowing water to flow along paths that may be interrupted by depressions, such as lakes or impact craters on Mars. The program identifies all pits in DEM and raises the elevation to the level of the lowest pour point around their edges. But, in a few cases, this step is not sufficient on Martian topography, because of large impact craters or tectonic faults disrupting the continuity of a preexisting flow path. Commonly, a local mask is also applied to artificially modify

Table 2. Age of Valley Networks

\begin{tabular}{lcc}
\hline Region & Age of Valley Networks & References \\
\hline Alba Patera & Early Amazonian & {$[$ Fassett and Head, 2008] } \\
Echus Plateau & Late Hesperian-Early Amazonian & {$[$ Fassett and Head, 2008] } \\
[Mangold et al., 2004] \\
Holden/Eberswalde crater & Late Hesperian & Mangold et al., 2012a \\
Warrego Vallis & Late Noachian-Early Hesperian & {$[$ Fassett and Head, 2008] } \\
(Thaumasia highlands) & & {$[$ Ansan and Mangold, 2006] } \\
Vichada Valles & Late Noachian-Early Hesperian & {$[$ Fassett and Head, 2008] } \\
(Tyrrhena Terra) & Late Noachian & {$[$ Mest et al., 2010] } \\
SW Newcomb crater & Middle to Late Noachian & {$[$ Tanaka, 1986] } \\
Terra Cimmeria & & {$[$ Scott et al., 1986] } \\
& & {$[$ Greeley and Guest, 1987] } \\
East Huygens crater & Late Noachian & {$[$ Irwin and Howard, 2002] } \\
& & {$[$ Fassett and Head, 2008] } \\
\hline
\end{tabular}




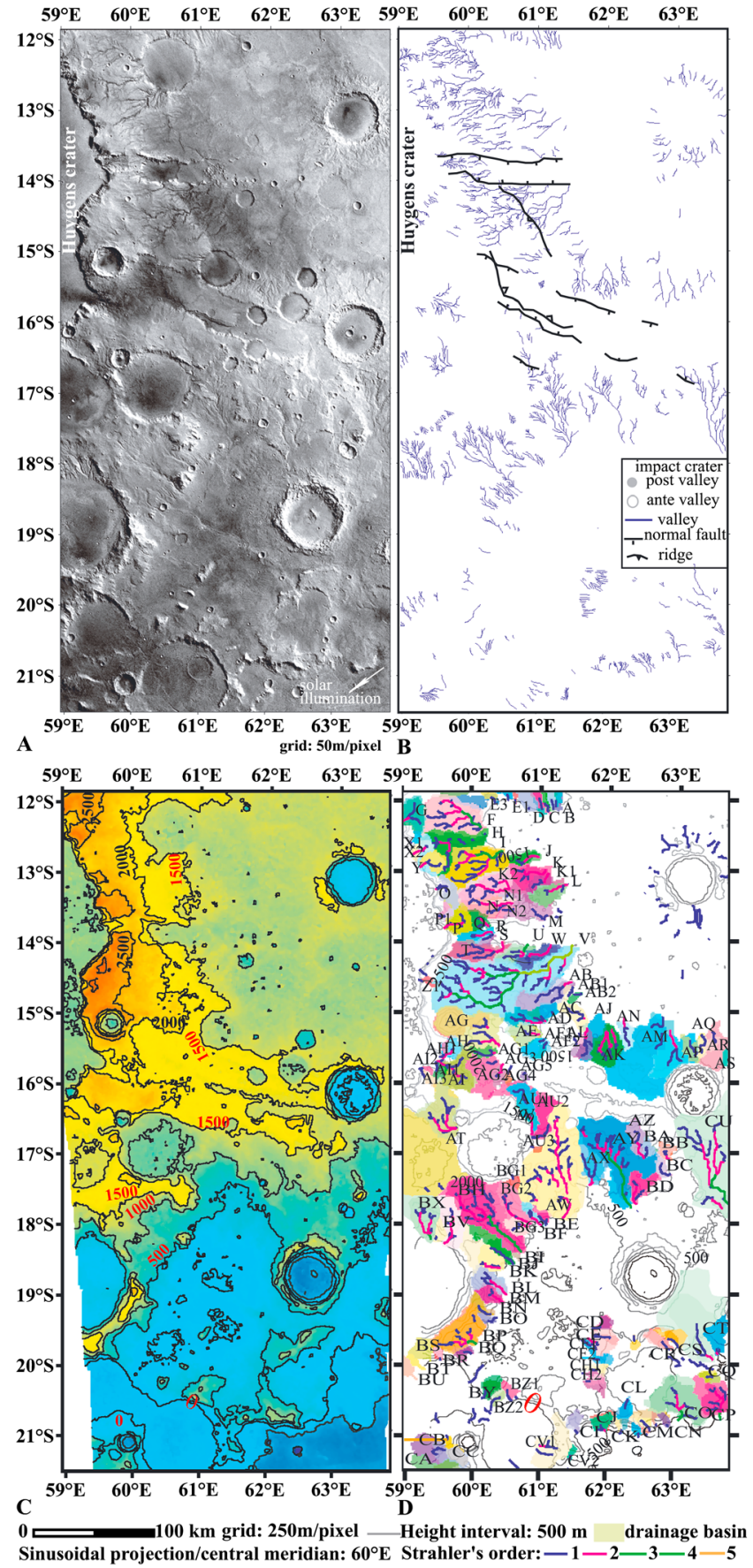

Figure 3. East Huygens crater: (a) HRSC image, (b) interpretative map of valley networks in HRSC image, (c) HRSC DEM, and (d) valley networks and watersheds extracted from DEM with their Strahler organization.

the original topography by uplift, and excluding thus these areas from flooding [e.g., Stepinski and Collier, 2004]. In our DEMs, the modified area is often very low, i.e., $<2 \%$ in average.

[15] From the corrected DEM, the second step creates a grid of flow direction (or slope grid) from each pixel to its steepest downslope neighbor in a $3 \times 3$ pixel neighborhood [O'Callaghan and Mark, 1984]. This grid indicates the direction in which surface water will flow from one pixel to another by calculating the direction of steepest descent from each cell.

[16] The third step consists to determine the area that can potentially produce runoff to a pixel of interest (i.e., outlet) [Tarboton et al., 1991], using a flow accumulation threshold, permitting both locations of stream channels and watershed delineation. This point is also crucial for valley organization and requires human adjustments in the choice of threshold, as discussed by Stepinski and Collier [2004], Ansan and Mangold [2006, 2008], and Mest et al. [2010]. The arbitrarily chosen threshold results in stream networks overextracted or under-extracting. Testing different thresholds, the best value is reached when the extracted stream network coincides as much as possible with valleys mapped from images. Note that the spatial resolution of HRSC DEMs is usually $\sim 3$ times smaller than that of the HRSC images, the stream networks extracted from DEMs have a lower number of tributaries, corresponding to major valleys visible on images. The result on morphometric parameters, such as drainage density, is a decrease by a factor of $\sim 2$ (e.g., drainage density is $0.22 \mathrm{~km}^{-1}$ for the HRSC image with a resolution of $50 \mathrm{~m} . \mathrm{pixel}^{-1}$ while it is $0.11 \mathrm{~km}^{-1}$ for the HRSC DEM with a resolution of $250 \mathrm{~m} . \mathrm{pixel}^{-1}$ at Huygens [Ansan et al., 2008]).

[17] In summary, the method used is semiautomatic because a human intervention is necessary to correct the Martian topography locally disrupted by large impact craters and tectonic structures and determine the best threshold for flow accumulation after the inspection of valley networks on images. Despite these limitations, this classical method has been used by numerous authors for extracting valley network from MOLA data [e.g., Mangold et al., 2004; Stepinski and Collier, 2004; Stepinski and Stepinski, 2005; Ansan and Mangold, 2006; Luo and Stepinski, 2006; Mest et al., 2010; Hynek et al., 2010].

[18] This software helps us to determine the probable runoff flow path inside valleys from the HRSC DEMs. The location of probable stream channels on Mars detected by DNR hydromod routine was then checked with HRSC nadir images. Valley networks that were not visible in HRSC images (e.g., in flat areas, in closed depressions with flat interiors, in small impact craters, etc.) were removed. The resulting set of valleys extracted from the HRSC DEM was used for deriving all geomorphic parameters.

\subsection{Morphometric Parameters}

[19] The morphometric parameters compiled from the valleys extracted from HRSC DEMs are the total stream length inside a drainage basin Ltot, the drainage basin area $A$, which is the area in which water and sediments are collected and distributed, bounded by the highest topographic points and the drainage density $D$, which corresponds to the total stream length Ltot divided by the area $A$ of each drainage basin.

[20] In addition, valley networks consist of valleys that are arranged in branch-like pattern, in which the relationship between different orders of valleys can be expressed in mathematical terms. Many models have been developed [e.g., Horton 1945; Strahler, 1952; Shreve, 1966], but the system of valley order by Strahler [1952] was often used for Martian networks [e.g., Carr, 1995; Cabrol and Grin, 2001; Ansan and Mangold, 2006; Hynek et al., 2010] and we chose to use that one. In the Strahler' [1952] system, 


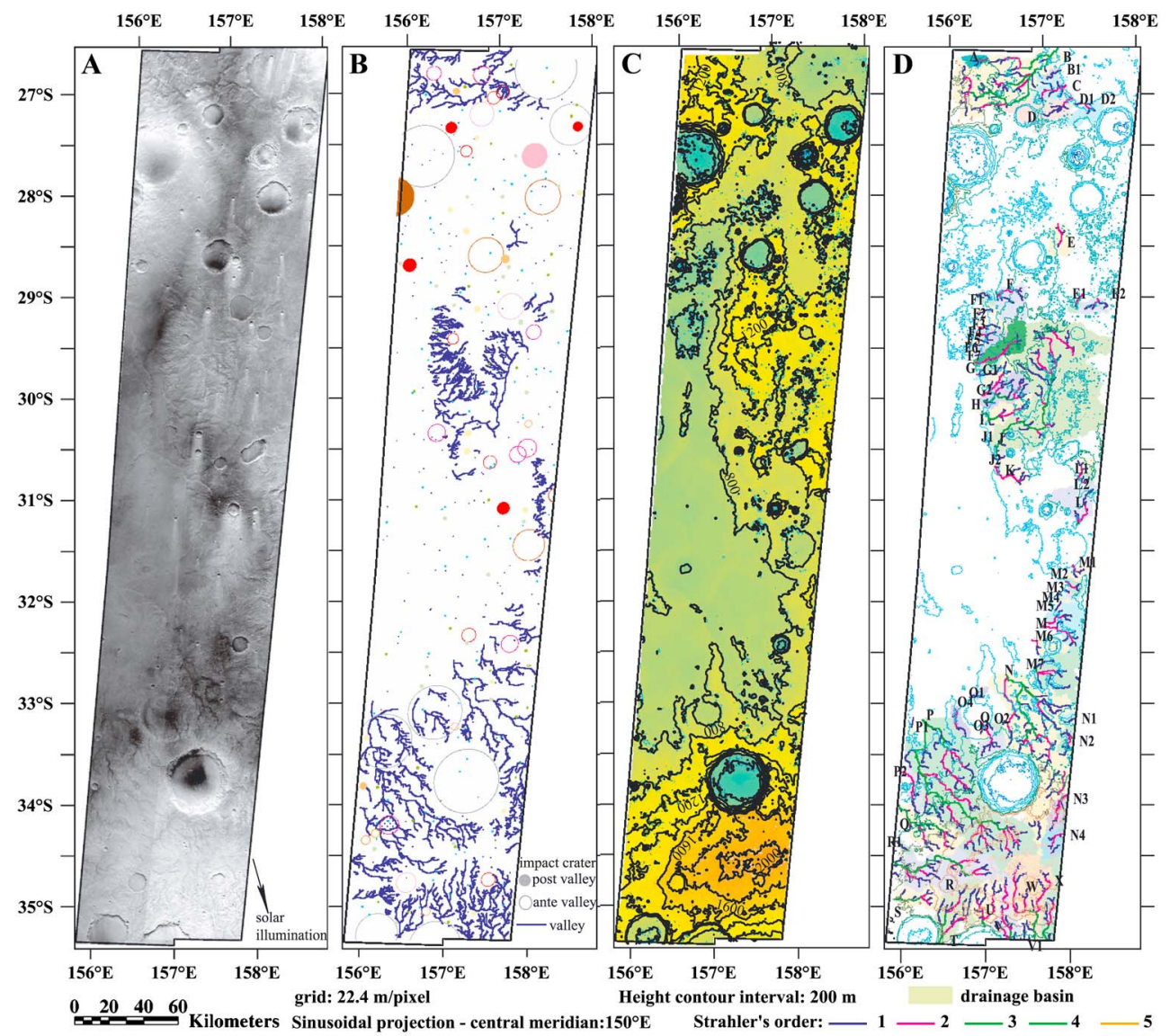

Figure 4. Terra Cimmeria near Kepler crater: (a) HRSC image, (b) interpretative map of valley networks in HRSC image, (c) HRSC DEM, and (d) valley networks and watersheds extracted from DEM with their Strahler organization.

the lowest order is a valley with no tributary and is designated as a first-order valley. Where two valleys of first order join together, they form a second-order valley and so on. Where two valleys of different orders join together, the following valley retains the highest order. The highest order of valley network corresponds to that of the main tributary (outlet). Subsequently the Strahler organization of the valleys enables us to define the length ratio $R l$, which is the ratio between the average length of valley of a given order $L_{u}$ to that of the next higher order $L_{u+1}$ [Horton, 1945; Strahler, 1952, 1968], and the bifurcation ratio (Rb), which is the ratio of the number of valleys for a given order $N_{u}$ to the number of valleys in the next higher order $N_{u+1}$.

[21] For the largest networks, we also applied Hack's law [Hack, 1957], which is a well-known parameter for determining the distribution of valleys or stream inside their watershed. This law is an empirical power law relationship between the drainage basin area and the length of the stream, measured from the mouth of the basin to the crest of the drainage divide along the stream channel. It is commonly written in the form: $L \sim A^{n}$ where $L$ is the main stream length. It is generally accepted that the average value of the exponent $n$ for terrestrial valley networks is slightly below 0.6 [e.g., Hack, 1957; Rigon et al., 1996]. For a given value of $n$, Hack's law implies that basins behave anisotropically, becoming longer and narrower as their size increases [Ijjasz-Vasquez et al., 1993].
[22] Last, a study of valley depths was performed for valley networks having Strahler order higher than 2. For each drainage basin, the mean depth of valleys of a given order was measured along a $100 \mathrm{~m}$ long valley segment at $1 \mathrm{~km}$ upstream from each valley junction. A comparative study of the valley depth versus Strahler orders was then performed in each region. The intensity of fluvial erosion on Mars over time can then be better understood by plotting the incision depth of valleys versus their age of formation.

\section{Valley Networks Analyses}

\subsection{Valley Networks Ages}

[23] We study eight Martian regions essentially localized along the equatorial belt (Figure 1) between $10^{\circ} \mathrm{N}$ and $30^{\circ} \mathrm{S}$, except Alba Patera $\left(\sim 50^{\circ} \mathrm{N}\right)$, and Thaumasia Highlands $\left(\sim 40^{\circ} \mathrm{S}\right)$. Based on the age of incised terrain [Tanaka, $1986]$ and the age of valley networks, defined by different methods of crater counting, including that of the "buffer crater counting" [e.g., Fassett and Head, 2008; Bouley et al., 2010] and that of the "crater counting throughout the entire watershed" [e.g., Ansan and Mangold, 2006; Mangold et al., 2008; Bouley et al.,2010], we defined three categories of valley networks (Table 2) corresponding roughly to the three main epochs of Mars: Noachian, Hesperian, and Amazonian. The Noachian category actually corresponds to those networks formed from the Middle Noachian to the 

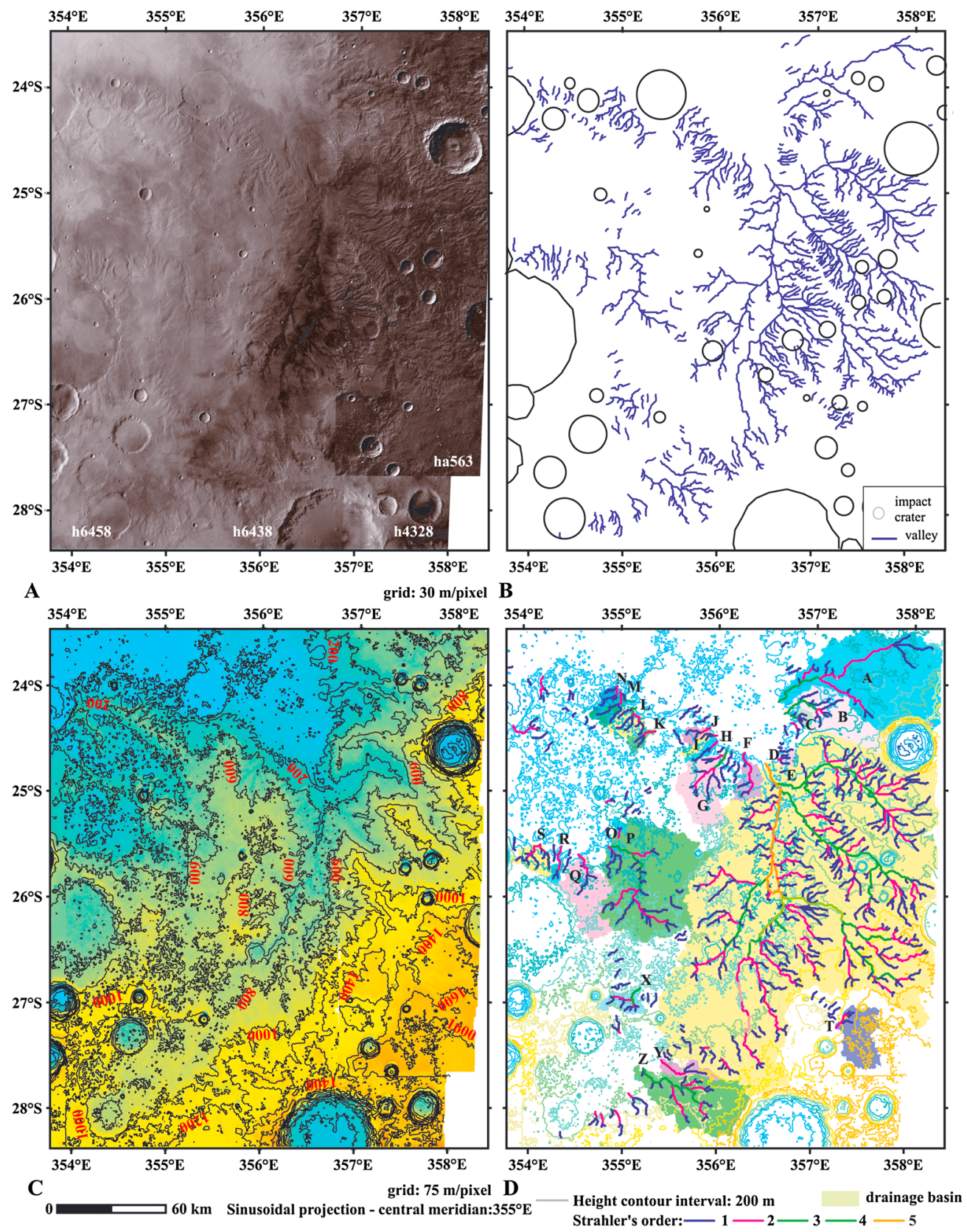

Figure 5. SW Newcomb crater: (a) HRSC image, (b) interpretative map of valley networks in HRSC image, (c) HRSC DEM, and (d) valley networks and watersheds extracted from DEM with their Strahler organization.

Early Hesperian, which are generally referred to the classical Late Noachian episode of fluvial resurfacing [e.g., Howard et al., 2005; Irwin et al., 2005a; Ansan and Mangold, 2006; Fassett and Head, 2008; Hynek et al., 2010].

[24] Late stages are classified in two categories: valleys formed in the Hesperian, corresponding mainly to episodes observed in the Late Hesperian, and those formed in the Amazonian. In Fassett and Head [2008], late stage valleys were all interpreted to be the result of episodic activity of an unknown origin. However, recent works show a much more developed Late Hesperian activity going from the initial study on the plateaus of Echus Chasma, and extending to many alluvial fans in southern craters [Mangold et al., 2004; Grant and Wilson, 2011;
Mangold et al., 2012b]. In contrast, valleys on volcanoes such as Alba Patera seem much more restricted to volcanic edifices of the Early to Middle Amazonian period, without clear evidence for connections with the Late Hesperian stage of activity. Thus, the Late Hesperian category includes Echus Plateau and west Eberswalde crater valleys, whereas the Amazonian category is represented by Alba Patera networks, one of the most developed of these types of valleys.

[25] Questions exist with regards to the fact that the Noachian valleys activity may have extended from Noachian to Hesperian or even Amazonian, thus not requiring the presence of three distinct stages. Indeed, several authors have noticed that ages of the youngest valley activity 

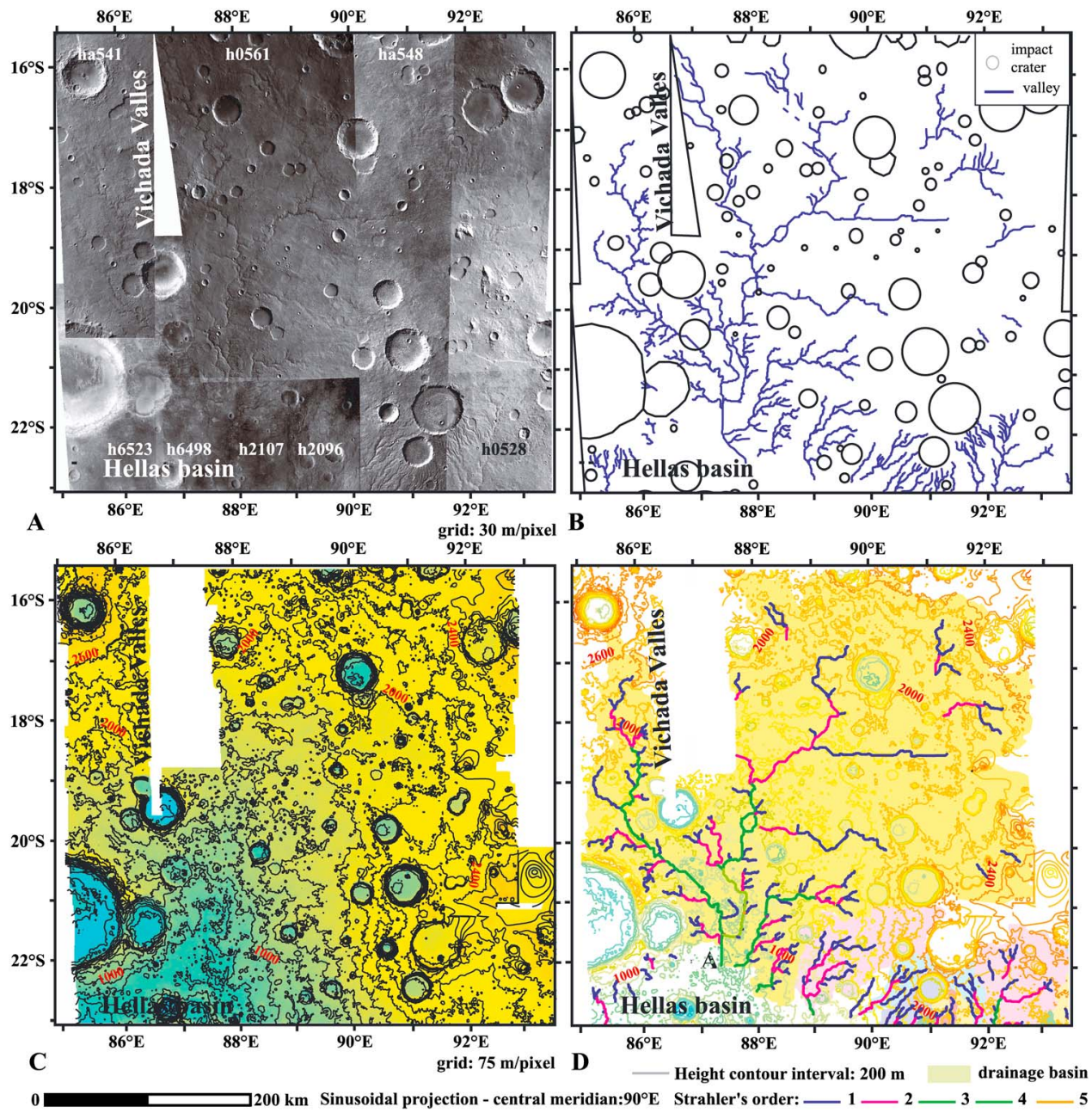

Figure 6. Vichada Valles in Tyrrhena Terra: (a) HRSC image, (b) interpretative map of valley networks in HRSC image, (c) HRSC DEM, and (d) valley networks and watersheds extracted from DEM with their Strahler organization.

in the Noachian terrains are actually Hesperian (e.g., in Parana Valles, [Bouley et al., 2010]). However, several impact craters have widespread ejecta that cover previous valleys: the Hesperian crater Jones has an ejecta blanket burying sections of Samara and Loire Valles, with only local reactivation through small outflow-like activity distinct from previous intense erosion [Mangold et al., 2012b]. The Hesperian crater Holden created secondary craters having impacted Noachian valley systems without any visible reactivation [Mangold et al., 2012a]. In general, most ancient valleys do not show terminal fans and the usual reason is the burial of the distal section of the valleys by subsequent Hesperian lava flows [e.g., Carr, 1995; Fassett and Head, 2008]. This process is widespread through all uplands and is applicable to the valleys chosen. Because of the lack of stratigraphic relationships, it is more difficult to assess that the Late Hesperian activity observed at Echus or Eberswalde (as well as all the southern latitudes alluvial fans) was not prolonged during the Amazonian. So, as the valley categories represent valleys eroding into bedrock of, respectively, Noachian, Hesperian, and Amazonian age, we therefore simply refer to these three periods for the three corresponding categories, remembering that the
Hesperian and Amazonian activity may correspond to a single category (late-stages valley networks).

\subsection{D Geometry of Valley Networks}

[26] For each of the three categories, we show a map of valley networks extracted from HRSC images and DEMs. Mapping of valley networks from HRSC images allows us to define the morphologic and geologic contexts, the plan view geometry of valley, and their spatial distribution. The semiautomatic mapping of valley networks from HRSC DEM allows us to define the "paleo-flow" trend in relation to the topographic slope and the vertical geometry of valley (depth of incision). Although manual mapping is dependent on interpretations, the map from images systematically shows more details and more valleys than those extracted from DEM because the spatial resolution of images is three times higher than the DEM resolution.

[27] Five of the eight selected regions are in Noachian terrains: the eastern rim of Huygens crater $\left(59^{\circ}-64^{\circ} \mathrm{E} /\right.$ $12^{\circ}-21.5^{\circ} \mathrm{S}$, Figure 3$)$, an area near Kepler crater in Terra Cimmeria $\left(155^{\circ}-158^{\circ} \mathrm{E} / 26.5^{\circ}-35^{\circ} \mathrm{S}\right.$, Figure 4$)$, an area in the southwestern ejecta of Newcomb crater located north of Noachis Terra $\left(354^{\circ}-358^{\circ} \mathrm{E} / 23.2^{\circ}-28.5^{\circ} \mathrm{S}\right.$, Figure 5), an 

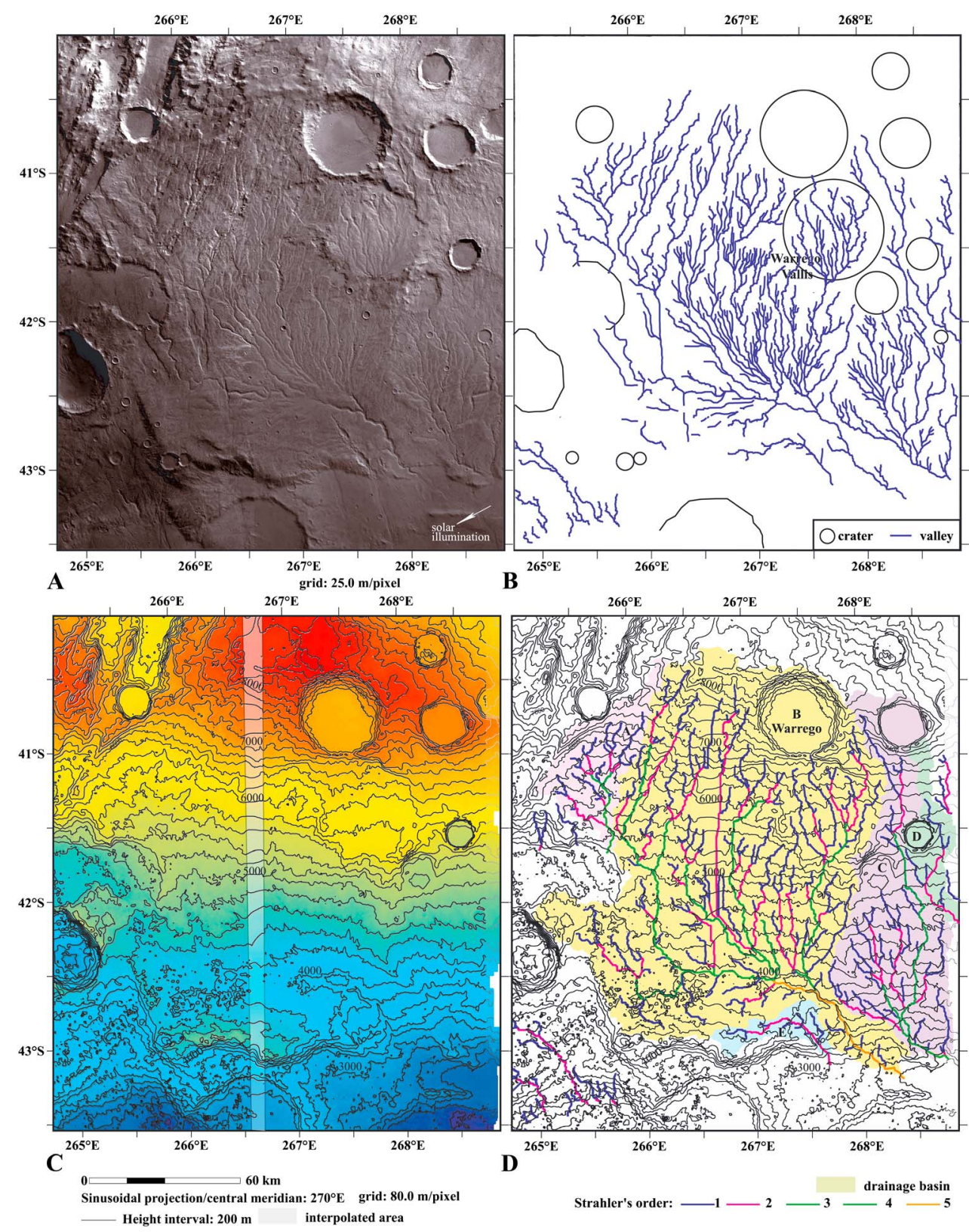

Figure 7. Warrego Vallis in Thaumasia highlands: (a) HRSC image, (b) interpretative map of valley networks in HRSC image, (c) HRSC DEM, and (d) valley networks and watersheds extracted from DEM with their Strahler organization.

area in the south of Tyrrhena Terra including Vichada Valles $\left(85^{\circ}-93.5^{\circ} \mathrm{E} / 15.5^{\circ}-23.0^{\circ} \mathrm{S}\right.$, Figure 6$)$, and the southern central part of Thaumasia highlands, including Warrego Vallis $\left(265^{\circ}-269^{\circ} \mathrm{E} / 40^{\circ}-44^{\circ} \mathrm{S}\right.$, Figure 7$)$. All of these Noachian regions are characterized by heavily cratered terrains with large degraded and subdued impact craters incised by dense branched valley networks over the local topography. They correspond to the dissected highlands (Npld) defined from Viking images and dated to the Noachian epoch [Scott et al., 1986; Tanaka, 1986]. All valley networks have numerous tributaries that incised widespread subrectangular areas with a quite homogeneous spatial distribution, with exception of Vichada Valles, which display a relatively small number of tributaries in its eastern part (Figure 6). Valleys progressively widen up to several kilometers and deepen from the head to the outlet.
They debouch onto local plains that are often large subdued cratered terrains (Npl2, Tanaka, 1986), interpreted as the result of the early stage of widespread volcanism or mantling during the Late Noachian/Early Hesperian (e.g., East Huygens crater [Ansan et al., 2008], Terra Cimmeria [Irwin and Howard, 2002; Ansan et al., 2008] and SW Newcomb crater), or large volcano-sedimentary basin (e.g., Vichada Valles debouching in Hellas basin), or widespread Hesperian lava plains (e.g., the outlet of Warrego Vallis covered by Icaria Planum [Ansan and Mangold, 2006]).

[28] For each area, many watersheds were extracted from the HRSC DEMs covering areas greater than $2000 \mathrm{~km}^{2}$ and related to those identified on HRSC images (e.g., 60 basins for East Huygens crater, Figure 3d; 61 basins for Terra Cimmeria, Figure 4d; 33 basins for SW Newcomb craters, 

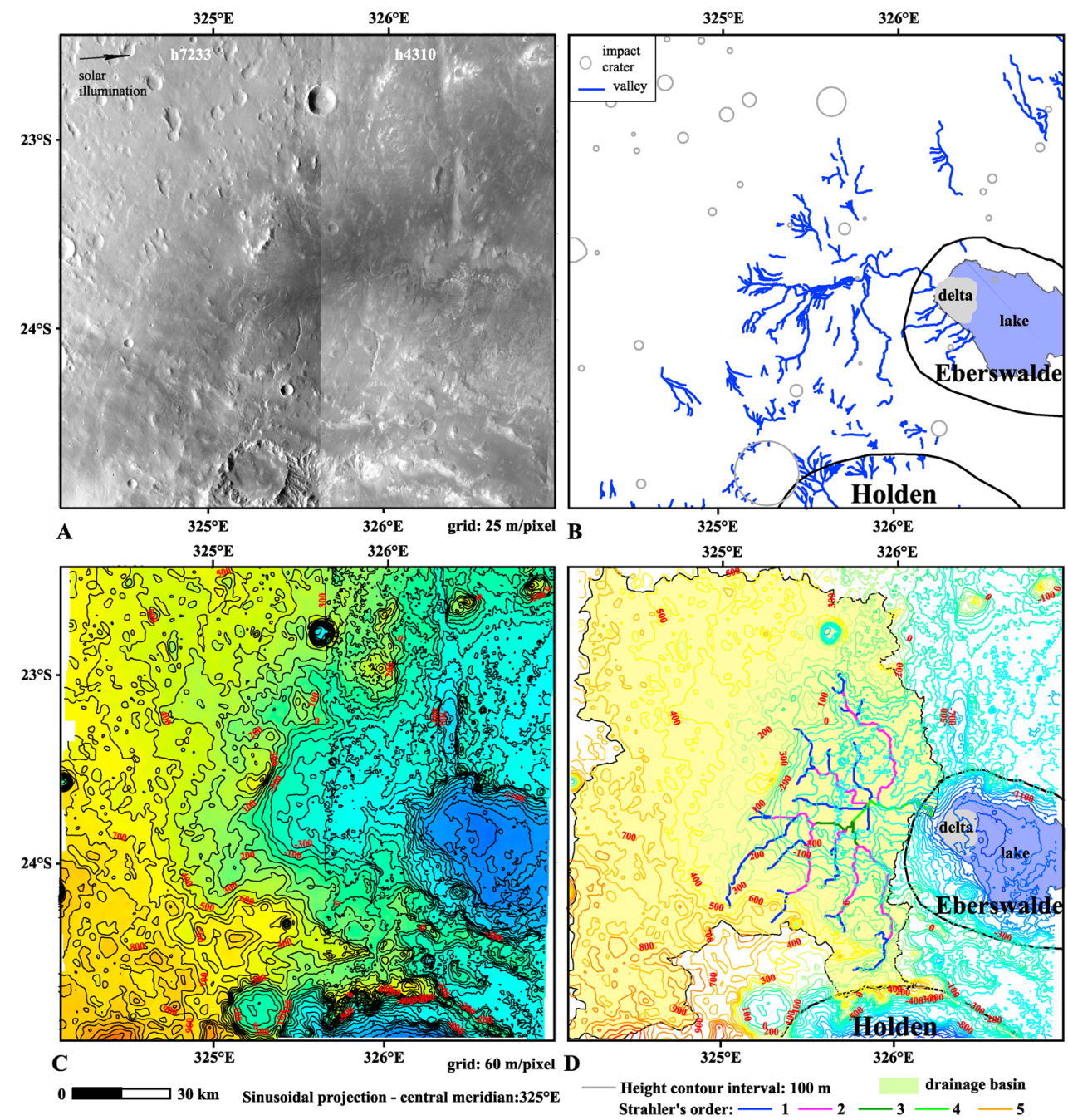

Figure 8. Valley network in Holden ejecta debouching in Eberswalde crater: (a) HRSC image, (b) interpretative map of valley networks in HRSC image, (c) HRSC DEM, and (d) valley networks and watersheds extracted from DEM with their Strahler organization.

Figure 5d; 13 basins including that of Vichada Valles for Tyrrhena Terra, Figure 6d; 5 basins including Warrego Vallis for Thaumasia Highlands, Figure 7d). The geographical and topographic settings of these basins show a strong diversity with a majority of basins standing at $1-2 \mathrm{~km}$ in elevation (e.g., East Huygens crater, SW Newcomb crater, Terra Cimmeria), but there are also basins standing at higher elevation, such as Warrego Vallis whose head valleys start at $\sim 9$ $\mathrm{km}$, or at lower elevation, such as those in the northeastern boundary of Hellas basin.

[29] Two regions show valley networks that incised Hesperian terrains: the north ejecta of Holden crater at the west of Eberswalde crater $\left(324^{\circ}-327^{\circ} \mathrm{E} / 22.5^{\circ}-25.0^{\circ} \mathrm{S}\right.$, Figure 8) [Mangold et al., 2012a] and Echus Plateau located at the west of the Echus Chasma canyon $\left(277.5^{\circ}-279^{\circ} \mathrm{E} /\right.$ $1.5^{\circ} \mathrm{N}-2.1^{\circ} \mathrm{S}$, Figure 9) [Mangold et al., 2004, 2008]. They show two distinct valley organizations. The northern ejecta blanket of Holden crater is incised by a poorly developed valley network with tributaries showing a nearly constant width from the head to the downward junctions. The outlet shows the well-known delta fan in a paleo-lake of Eberswalde crater (Figures $8 \mathrm{a}$ and $8 \mathrm{~b}$ ). Although the overall number of valleys is low, the branching pattern fit that expected for a valley network. From HRSC images, the apparent basin area seems to be limited to a small surface comparable in size to the Eberswalde surface, i.e., $\sim 5000 \mathrm{~km}^{2}$. As fluvial activity crosscuts Holden ejecta, and thus postdates Holden crater, whose formation age is estimated from crater counts around the Early Hesperian-Late Hesperian transition [e.g., Mangold et al., 2012a], valley networks developed during the end of the Hesperian epoch.

[30] Valley networks were first identified on the Echus Plateau from their distinct thermal properties on THEMIS images [Mangold et al., 2004]. Valleys appear relatively narrow and shallow but they form valley networks (Figures 9a and 9b) with two types of branching patterns: dendritic in the northern part of the HRSC image and parallel in the southern part, suggesting that the regional topographic slope controlled their organization [Mangold et al., 2004. The valleys incised the Late Hesperian plateau [Tanaka et al., 1992] and are buried by Amazonian lava flows to the north of the Echus Plateau [Mangold et al., 2004, 2008]. We extracted 45 basins with $\sim 12$ being significant (main valleys $>30 \mathrm{~km}$ ) from the HRSC DEM in this 


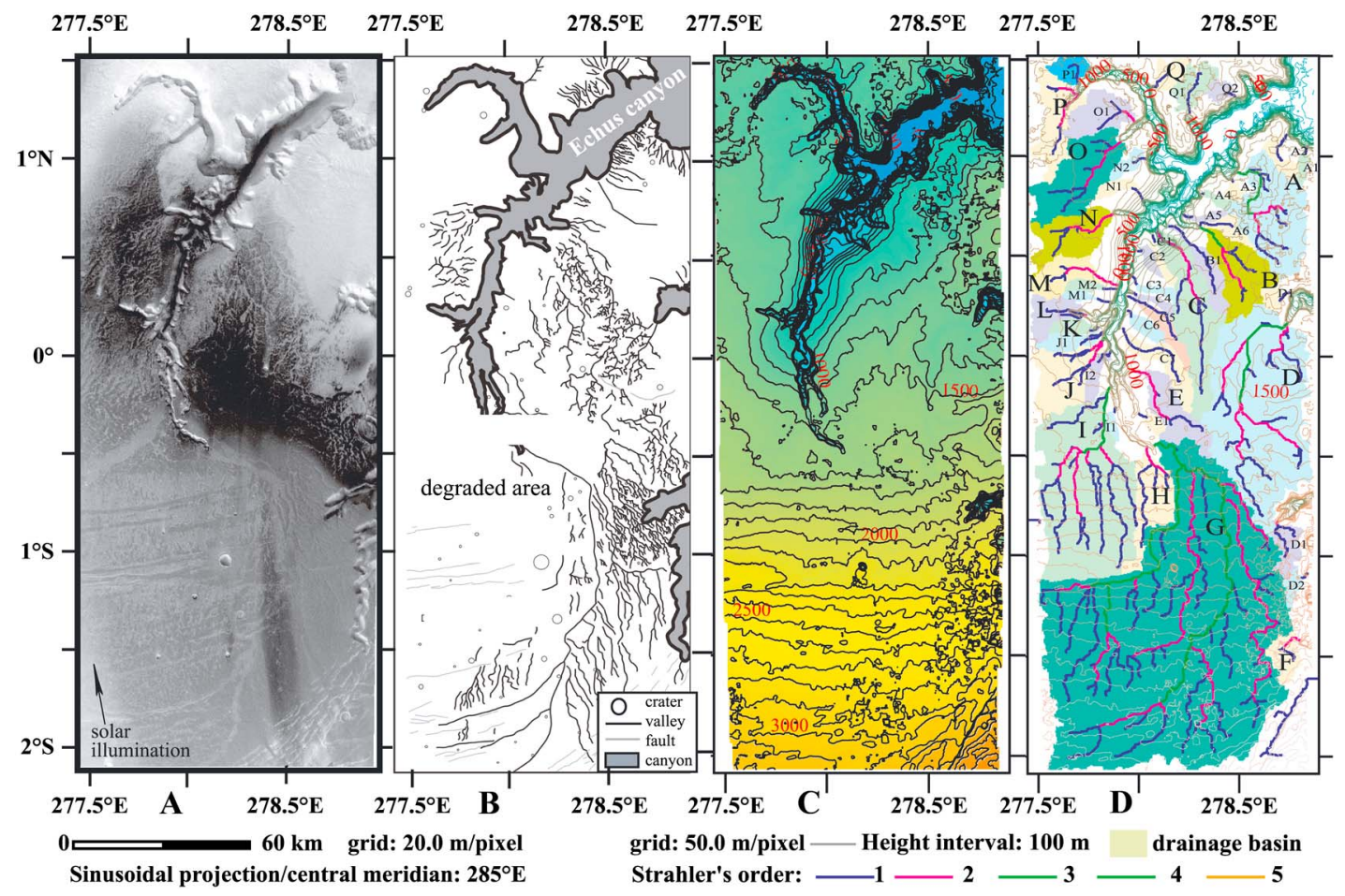

Figure 9. Echus Plateau: (a) HRSC image, (b) interpretative map of valley networks in HRSC image, (c) HRSC DEM, and (d) valley networks and watersheds extracted from DEM with their Strahler organization.

area located at relatively high elevation $(3.5-0.8 \mathrm{~km})$. They are all connected to Echus Chasma, suggesting that they formed during or after the Chasma opening [Mangold et al., 2004, 2008].

[31] One region in which valley networks dated to the Amazonian epoch is Alba Patera [Gulick and Baker, 1990; Baker et al. 1992; Fassett and Head, 2008]. The HRSC image shows very dense valley networks whose interfluves often correspond to volcanic cones (e.g., volcanic cones at $251.6^{\circ} \mathrm{E} / 46.5^{\circ} \mathrm{N}$ in Figure $\left.10 \mathrm{a}\right)$. Valleys are $10 \mathrm{~s}$ of kilometer long, $<15 \mathrm{~km}$ wide, and are distributed with a parallel branching pattern following the local topography. Valleys contain inner central, linear, few kilometers wide depressions, well outlined by solar illumination that are interpreted

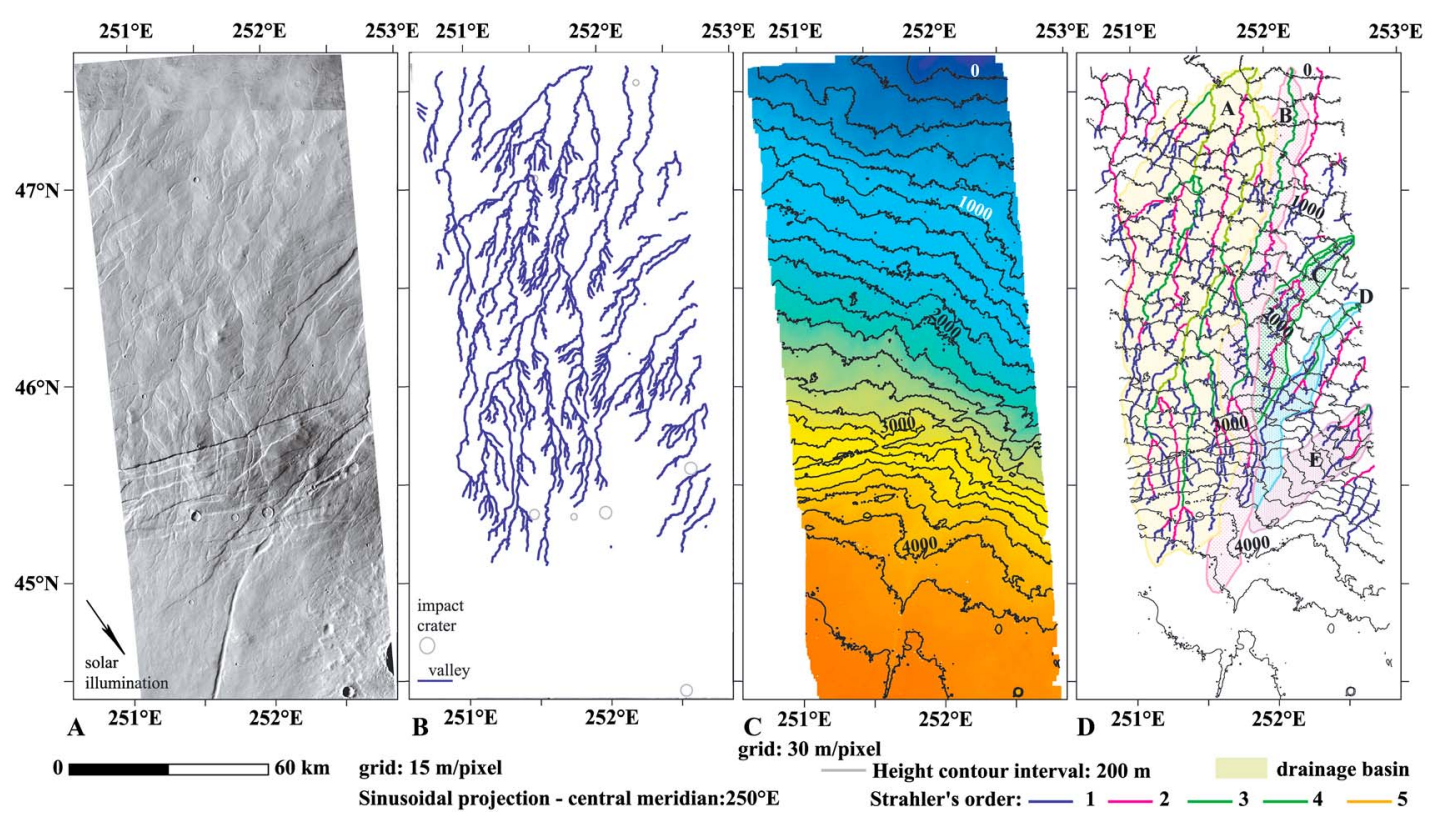

Figure 10. Valley networks in Alba Patera: (a) HRSC image, (b) interpretative map of valley networks in HRSC image, (c) HRSC DEM, and (d) valley networks and watersheds extracted from DEM with their Strahler organization. 
Table 3. Morphometric Characteristics for Valley Networks With a Strahler Order Higher or Equal to $3^{\mathrm{a}}$

\begin{tabular}{|c|c|c|c|c|c|c|c|c|}
\hline & \multirow[b]{2}{*}{ nb Basin } & \multirow{2}{*}{$\frac{\langle\mathbf{A}>}{\left(\mathrm{km}^{2}\right)}$} & \multirow{2}{*}{$\frac{<\text { Ltot }>}{(\mathrm{km})}$} & \multirow{2}{*}{$\frac{<\mathbf{D}>}{\left(\mathrm{km}^{-1}\right)}$} & \multicolumn{2}{|c|}{ Strahler Order } & \multirow[b]{2}{*}{$\mathbf{R b}$} & \multirow[b]{2}{*}{$\mathbf{R I}$} \\
\hline & & & & & Max & Mean & & \\
\hline Alba Patera & 5 & 1450.3 & 322.7 & 0.23 & 4 & 3 & 3.6 & 2.5 \\
\hline Echus Plateau & 6 & 1435.4 & 288.5 & 0.18 & 4 & 3 & 3.1 & 1.6 \\
\hline Holden/eberswalde crater & 1 & $12,715.7$ & 522.1 & 0.04 & 4 & & 2.9 & 1.8 \\
\hline Thaumasia highlands & 3 & 6491.8 & 1075.4 & 0.17 & 5 & 4 & 3.1 & 1.8 \\
\hline Tyrrhena Terra (Vichada Valles) & 1 & $110,688.4$ & 3489.9 & 0.03 & 4 & & 4.7 & 2.1 \\
\hline SW Newcomb crater & 9 & 2985.9 & 410.5 & 0.15 & 5 & 3 & 3.3 & 2.3 \\
\hline Terra Cimmeria & 19 & 886.5 & 181.1 & 0.22 & 4 & 3 & 3.4 & 2.1 \\
\hline East Huygens crater & 13 & 1446.9 & 175.9 & 0.13 & 4 & 3 & 3.3 & 2.0 \\
\hline
\end{tabular}

${ }^{\mathrm{a}} \mathrm{Nb}$ basins number of basins, $<\mathrm{A}>$ mean watershed area, $<$ Ltot $>$ mean of total length of tributaries, $<\mathrm{D}>$ mean drainage density at spatial HSRC DEM resolution, $<\mathrm{D} 1>$ mean drainage density at $75 \mathrm{~m}$.pixel ${ }^{-1}$ resolution, $\mathrm{Rb}$ mean bifurcation ratio, and $\mathrm{Rl}$ mean length ratio.

as inner channels. The depth of these channels cannot be extracted from the HRSC DEM because of their low vertical resolution, but valley depths are measured. Valleys are arranged with a parallel branching pattern following the local topography. Although the valley organization shows that the paleo-rivers flowed to the north, parallel to the north side of Alba Patera, the latter is disturbed by normal faults. Despite the faults, it was possible to extract five valley networks from HRSC DEM (Figure 10d), because normal straight faults are located on the head basin area on these HRSC data. Note that valleys were observed at topographic slope of $\sim 1.5^{\circ}$, i.e., at the boundary of Alba Patera summit and the north side stand at $\sim 4 \mathrm{~km}$ in elevation (Figure 10c).

[32] Based on the manual and semiautomatic mapping from the HRSC data, we observed similarities and differences in 2D plan view geometry as a function of Martian epochs. In general, Noachian valleys are wider and longer. However, whatever their age, the geometry and topography of all valleys are consistent with downslope flow. Valleys are arranged in branching networks whose pattern is governed by local topographic slope: more parallel valleys occur when the slope is higher. Such a geometric similarity justifies application of morphometric parameters used for terrestrial valley networks as presented below.

\subsection{Morphometry}

[33] Based on the HRSC DEM mapping of valleys, we present morphometric parameters of 57 valley networks with Strahler orders $>2$ in all study regions (Table 3 ). There are several limitations for using these parameters. First, mapping of valley networks was made at slightly different spatial resolutions (from 30 to $250 \mathrm{~m} / \mathrm{pixel}^{-1}$ ). Second, the DEM areas are sometimes smaller than the actual extent of the watersheds. These effects introduce a slight bias in Strahler orders, but this only accounts for small number of basins $(<10 \%)$. Third, the mean drainage areas decreases with younger ages, ranging from $\sim 3000 \mathrm{~km}^{2}$ for Noachian watersheds to $\sim 1400 \mathrm{~km}^{2}$ for Hesperian and Amazonian ones (Table 3). Additionally, the mean total valley lengths decrease with younger age, from $\sim 500 \mathrm{~km}$ for Noachian networks to $\sim 300 \mathrm{~km}$ for Amazonian ones (Table 3 ). Nevertheless, these effects are minor: the studied areas are large enough to minimize statistical effects due to the choice of basins of differing ages. Valley networks from the Noachian category reach a Strahler order of 5, not significantly more than the maximum Strahler order of 4 found for younger valley networks (Table 3 ). We comment to this point later in the manuscript.
[34] The drainage densities obtained vary only slightly between categories of valley networks (Table 3). For Noachian basins, the mean drainage density is $\sim 0.15 \mathrm{~km}^{-1}$, except Vichada Valles whose drainage density is very low. For the Hesperian valley networks, the mean drainage density is $\sim 0.18 \mathrm{~km}^{-1}$ on the Echus Plateau and, by contrast, much lower west of Eberswalde with a drainage density of $0.05 \mathrm{~km}^{-1}$. For the Amazonian watersheds in Alba Patera, the drainage density is $\sim 0.23 \mathrm{~km}^{-1}$. As calculated drainage densities are dependent on detection of tributaries, the greater the spatial resolution of data, the better the detection of smallest tributaries. Most basins are mapped at DEM gridding within the same order of magnitude, which should not modify the order of magnitude of calculated drainage densities. The drainage densities measured are relatively constant $\left(0.1-0.2 \mathrm{~km}^{-1}\right.$ at $\sim 75$ m.pixel $^{-1}$ ) whatever the age of valley networks.

[35] A known property of Martian drainage densities is that some of the youngest ones display very high values with $1.5 \mathrm{~km}^{-1}$ for Alba [Gulick and Baker, 1990] and up to $1 \mathrm{~km}^{-1}$ for Echus Plateau [Mangold et al., 2004, 2008] when mapped using high resolution visible images. These values are higher than the drainage densities found when using the HRSC DEM as a base for the mapping (Table 3). This suggests that many tributaries of both networks (Alba and Echus Plateau) are too shallow to be detected in the HRSC DEM accuracy. This conclusion is not valid for Noachian valleys, which usually do not show such higher densities when mapped using images. One of the densest networks is Warrego Vallis, which gives $0.53 \mathrm{~km}^{-1}$ when mapped with images [Ansan and Mangold, 2006], so three times higher than that extracted from the HRSC DEM.

[36] Noachian valley networks extracted from Viking images have an average drainage density of $0.005 \mathrm{~km}^{-1}$ [Carr, 1995; Carr and Chuang, 1997; Cabrol and Grin, 2001], but the latter reaches $0.01 \mathrm{~km}^{-1}$ when using THEMIS daytime IR images combined with MOLA [Hynek et al., 2010]. Although our average drainage density for Noachian basins extracted from HRSC DEMs is one order of magnitude higher than those previously cited, it remains relatively low in comparison to those of younger basins. This suggests that the smaller tributaries associated with Noachian valleys are much less preserved and were likely modified by subsequent processes, such as burial by aeolian deposits. Such an interpretation may also explain why Noachian valley networks do not have higher Strahler orders.

[37] The bifurcation ratio $(\mathrm{Rb})$ is defined as the ratio of the number of valleys for a given order $(\mathrm{Nu})$ to the number of 

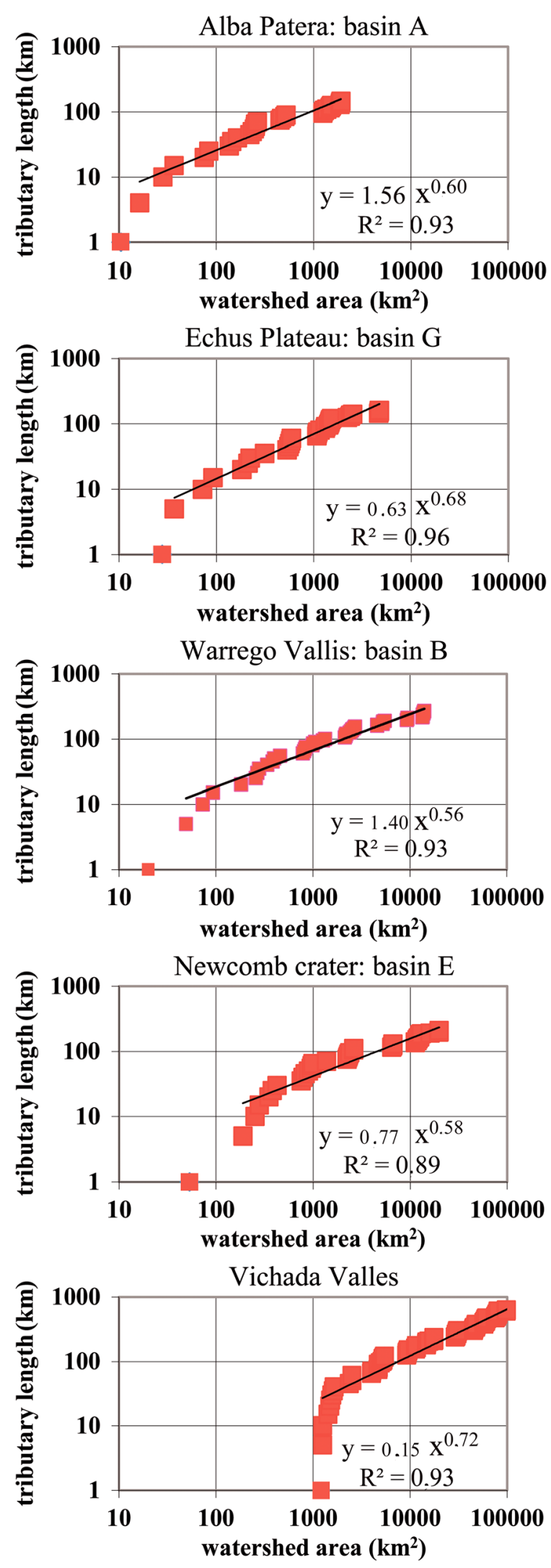

Figure 11. Graphs illustrating Hack's law written in the form: $\mathrm{L} \sim \mathrm{A}^{\mathrm{n}}$ where $\mathrm{L}$ is the main stream length, and $\mathrm{A}$ is the drainage basin area. Linear regression curve in log-log plot results in the $n$ exponent. valleys in the next higher order $(\mathrm{Nu}+1)$ [Schumm, 1956]. Whatever the study region, the mean value $(\mathrm{Rb})$ is $\sim 3$ (Table 3$)$. The length ratio $(\mathrm{Rl})$ is the ratio between the average length of valley of a given order (Lu) to that of the next higher order $(\mathrm{Lu}+1)$ [Horton, 1945; Strahler, 1952]. For each Martian data set, the Rl value is close to 2 (Table 3). These two parameters give values similar to terrestrial valley networks: the terrestrial $\mathrm{Rb}$ values range from 3.0 to 5.0 [Horton, 1945] and the terrestrial Rl value ranges from 1.5 to 3.5 [Horton, 1945; Strahler, 1968].

\subsection{Hack's Law}

[38] In terrestrial valley network studies, Hack's law [Hack, 1957] is frequently used to qualitatively determine the distribution of valleys or streams inside their watershed, considered as a consequence of self-similarity of stream channel planforms [Mandelbrot, 1983]. It is commonly written in the form: $L \sim A^{n}$ where $L$ is the main stream length, and $A$ is the drainage basin area. Mathematical constraints indicate that Hack's exponent $n$ should tend to the value of 0.5 for self-similar networks [Dodds and Rothman 2000].

[39] We used this empirical law for several widespread basins in all regions, and we determined values of the exponent $n$ (Figure 11 and Table 4) with good confidence. For all basins, we used the longest tributary joining the main one and we measured the area of the subdrainage basin for each given $5 \mathrm{~km}$ long valley segment along the longest one. The three examples of Noachian basins (Warrego Vallis, Newcomb, and Vichada Valles) show a great variety in drainage areas and tributary lengths (Figure 11). Despite this, there is an accurate regression curve in the log-log plots (Figure 11), even if the first $5 \mathrm{~km}$ long segment deviates from the law, as often observed on Earth [Dodds and Rothman 2000]. For the Hesperian and Amazonian basins, the drainage areas are slightly smaller than the Noachian ones and regression coefficient slightly better (Table 4).

[40] For all studied basins, the exponent $n$ ranges from 0.47 to 0.78 (Table 4 ) with a mean of 0.64 . The values of the Hack's exponent in our studied basins are close to values found in other basins of the Martian Southern highlands (e.g., 0.73 [Irwin et al., 2008] and 1.02 [Caprarelli and Wang, 2012]). No systematic differences exist between the three age categories: The nine Noachian basins averaged at 0.64 whereas the four younger ones also averaged at 0.64 .

Table 4. Hack's law ${ }^{\mathrm{a}}$

\begin{tabular}{lccc}
\hline Region & Basin & Exponent n & Confident R2 \\
\hline Alba Patera & $\mathrm{A}$ & 0.60 & 0.93 \\
Echus Plateau & $\mathrm{D}$ & 0.70 & 0.96 \\
& $\mathrm{G}$ & 0.68 & 0.96 \\
Holden/Eberswalde crater & $\mathrm{A}$ & 0.60 & 0.85 \\
Thaumasia Highlands & $\mathrm{B}$ (Warrego) & 0.55 & 0.93 \\
& $\mathrm{C}$ (East Warrego) & 0.47 & 0.94 \\
Tyrrhena Terra & A Vichada Valles & 0.72 & 0.94 \\
SW Newcomb crater & $\mathrm{A}$ & 0.52 & 0.94 \\
& $\mathrm{E}$ & 0.59 & 0.90 \\
& $\mathrm{P}$ & 0.66 & 0.95 \\
Cimmeria Terra & $\mathrm{P}$ & 0.78 & 0.97 \\
East Huygens crater & $\mathrm{I}$ & 0.71 & 0.91 \\
& $\mathrm{~V}$ & 0.78 & 0.97 \\
\hline
\end{tabular}

${ }^{\mathrm{a}}\left(\mathrm{L}=\alpha \mathrm{A}^{\mathrm{n}}\right.$ with L: Length of longer tributary of watershed. A: Area of Watershed. $\alpha$ and n: Constants). 

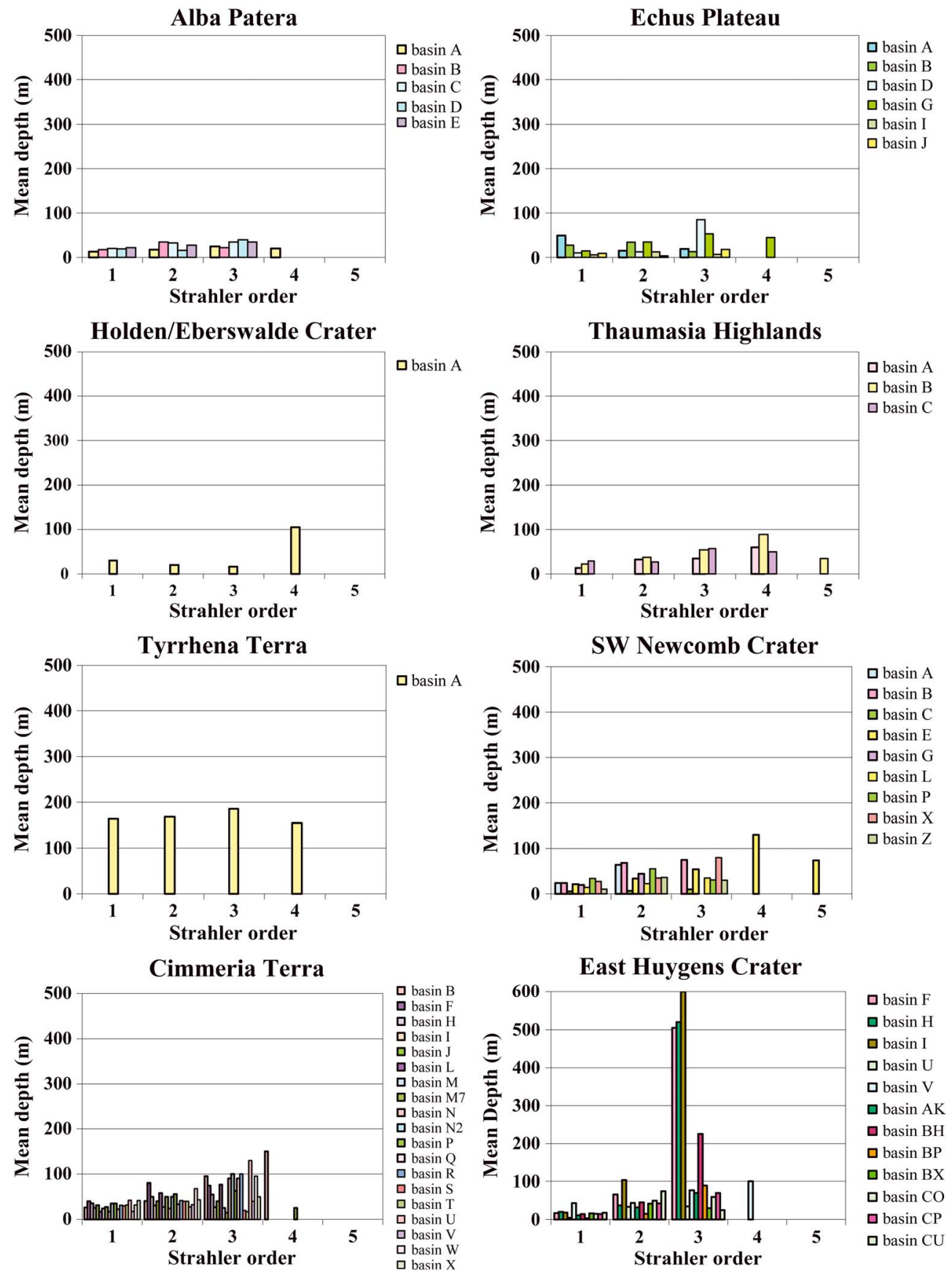

Figure 12. Mean depth versus Strahler order for each basin whose Strahler order is higher than 2 in eight regions.

[41] The mean value obtained at 0.64 is very close to the mean values obtained for terrestrial watersheds at $\sim 0.6$ [e.g., Hack, 1957; Rigon et al., 1996]. In addition, most values are within the usual range of Hack exponent found between 0.5 and 0.7 for most terrestrial networks [e.g., Rigon et al., 1996]. This geometric similarity with terrestrial networks strongly implies similar erosional processes.

\subsection{D Geometry of Valley Networks}

[42] Simply stated, the morphometric data are unable to distinguish differences between the three aged valley networks. Strahler order and drainage densities are of the same order of magnitude. Other parameters, like Hack and bifurcation ratio, show that they all follow the same geometric laws as terrestrial basins. However, as part of our analysis, we also performed valley depth analysis from the 3D information. In each drainage basin, we measured the valley depths for each valley of a given Strahler order, at $1 \mathrm{~km}$ upstream from the confluence. We represent this depth in three graphs. The first graph plots the mean valley depths versus Strahler orders for all basins to provide an overview of all the basins analyzed (Figure 12). The second graph plots the median valley depth by region, for a better statistical comparison between regions (Figure 13). Here, the median valley depth is calculated from 

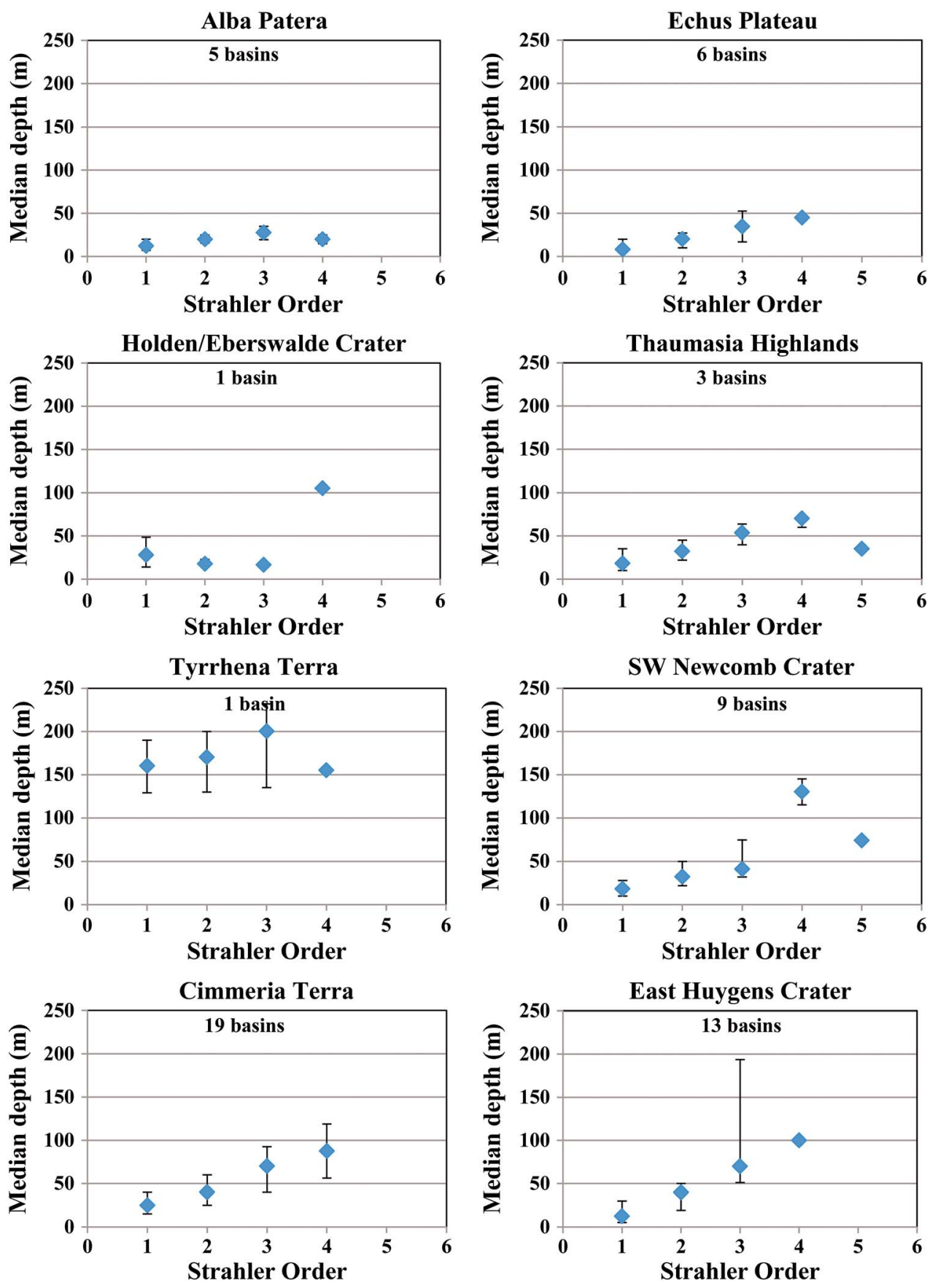

Figure 13. Median depth versus Strahler order for all basins whose Strahler order is higher than 2 in eight regions.

the depth of the total number of valleys for each order belonging to the same geographic region (Table 5). The third graph plots all single valley depths averaged by age to determine any evolution of valley incision over time (Figure 14).

[43] Several important results can be drawn from these three graphs: (i) The valley depth in each Strahler order is relatively homogeneous in the regions, i.e., there are no strong variations of depths at a given Strahler order (Figure 12); (ii) depth usually increases with Strahler order, as expected for erosion by fluvial activity (Figures 12 and 13); (iii) deeper valleys are found for the Noachian compared to younger networks; i.e., valleys at high Strahler orders are $100 \mathrm{~m}$ deep in
Noachian valleys, while a factor $\sim 3$ shallower for the three younger regions (Figures 12, 13, and 14).

[44] One exception exists for the first result (i). At East Huygens crater, the distribution of valley depths of order 3 shows two modes: mean depth of $\sim 500 \mathrm{~m}$ for three watersheds and mean depth of $\sim 100 \mathrm{~m}$ for others (Figure 12). The first mode is due to the cross section of valleys across old, degraded impact rims (Figure 3a) debouching at the inner bottom of filled craters. Two exceptions exist for the second result (ii). For Holden/Eberswalde, the main tributary is very deep because it crosses the old, degraded Eberswalde crater. For Vichada Valles in Tyrrhena Terra (Figure 6), and 
Table 5. Median Valley Depth (m) for Each Strahler Order in Each Region ${ }^{\text {a }}$

\begin{tabular}{|c|c|c|c|c|c|c|c|c|c|c|c|c|c|c|}
\hline Region & Order1 & $-\sigma \mathbf{h}$ & $+\boldsymbol{\sigma h}$ & Order2 & $-\sigma \mathbf{h}$ & $+\boldsymbol{\sigma h}$ & Order3 & $-\sigma h$ & $+\boldsymbol{\sigma h}$ & Order4 & $-\sigma h$ & $+\boldsymbol{\sigma h}$ & Order5 & nb Basin \\
\hline Alba Patera & 12.0 & 5.0 & 8.0 & 20.0 & 4.5 & 5.0 & 27.5 & 8.0 & 7.5 & 20.0 & 5.0 & 5.0 & & 5 \\
\hline Echus & 8.0 & 3.0 & 12.0 & 20.0 & 10.0 & 7.0 & 34.5 & 17.8 & 18.0 & 45.0 & & & & 6 \\
\hline Holden/ Eberswalde & 28 & 14 & 20.7 & 17.5 & 2.0 & 5.3 & 16.5 & 2.3 & 2.5 & 105.0 & & & & 1 \\
\hline Thaumasia & 18.0 & 8.0 & 17.0 & 32.0 & 10.1 & & 53.5 & 14.0 & 10.0 & 70.0 & 10.0 & 2.0 & 35.0 & 3 \\
\hline Tyrrhena & 160.0 & 30.0 & 31.0 & 170.0 & 30.0 & 40.0 & 200.0 & 32.0 & 65.0 & 155.0 & & & & 1 \\
\hline Newcomb & 18.0 & 8.0 & 10.0 & 32.0 & 10.0 & 18.0 & 41.0 & 9.0 & 33.8 & 130.0 & 15.0 & 15.0 & 74.0 & 9 \\
\hline Cimmeria & 25.0 & 10.0 & 15.0 & 40.0 & 15.0 & 20.0 & 70.00 & 30.0 & 22.5 & 87.50 & 31.3 & 31.3 & & 19 \\
\hline Huygens & 12.5 & 7.5 & 17.5 & 40.0 & 20.8 & 10.0 & 70.0 & 18.8 & 123.8 & 100.0 & & & & 13 \\
\hline
\end{tabular}

a" $\sigma h$ " corresponds to the difference in depth between the median and the first quartile, and the third quartile. "nb basin" corresponds to the number of basins in each region.

for the order 5 basins of Thaumasia (Figure 7) and Newcomb (Figure 5), the highest Strahler orders decrease in depth (Figures 12 and 13). Actually, the location of the main tributary in these three basins is in a plain that may correspond to alluvial deposits that may limit incision, thus explaining why these valleys are exceptions to the result (iii). In addition, for Vichada Valles, the fact that valleys are deep starting at their source (almost $100 \mathrm{~m}$ at order 1) suggests also that this basin has a distinct process forming the smaller valleys or that the local lithology is dramatically different. The small number of exceptions ( 7 basins over 57) to the general pattern (i) (iii) is insufficient to obscure the regional trends. West Eberswalde network and Tyrrhena Terra (Vichada Valles) have a specific geomorphic context that is not relevant for a general trend.

[45] We also compared details of six other regions (with the exception of Tyrrhena and Eberswalde) in Figure 13. A systematic increase in depth with higher Strahler orders is observed as already explained (result ii), but it is remarkable that this increase is relatively regular. For valley networks in the five Noachian regions, the median depth of Strahler order 1 is $\sim 20 \mathrm{~m}$ and reaches $\sim 100 \mathrm{~m}$ for the fourth Strahler order. For Echus Chasma plateau and Alba Patera, the median depth follows the same trend as that observed in others regions, but it remains lower than $\sim 25 \mathrm{~m}$, and the increase in depth by Strahler order is smaller (Figure 13). The actual comparison is biased by the fact that smaller orders may exist for ancient valleys, and were later degraded, but, here, the important point is the difference in the gradient from one order to another that would not depend to which orders they are actually compared.

[46] Assuming a linear trend plotting the valley depth $\left(\mathrm{d}_{\mathrm{n}}\right)$ in function of Strahler order $n$ ranging from 1 to 3 (Figure 13), the gradient of line $(\alpha)$ is calculated (equation (1)) for different regions:

$$
d_{n}=\alpha n+\beta
$$

[47] We fix $\beta$ at 0 (lines intercept the origin). Values of $\alpha$ for the Noachian regions vary from 14.6 in Newcomb crater region, to 17.3 in Thaumasia highlands, 21.6 in East Huygens crater, and 22.5 in Terra Cimmeria, whereas it is only of 10.8 in Holden/Eberswalde region and 9.6 in Alba Patera. The clear difference shows that the overall incision of the Noachian valleys was more pronounced than that of younger valleys.

[48] In order to visualize this effect more clearly, we plotted the evolution of median valley depths for each Strahler order throughout the Mars history (Figure 14 and Table 6). To do this, the median depth of the total number of valleys of each order belonging to each epoch is calculated: we use all valley depths of Alba Patera for the Amazonian epoch, those of Echus Plateau and Holden/Eberswalde crater for the Hesperian epoch, and valley depths of Thaumasia highlands, Tyrrhena Terra, SW Newcomb crater, Terra Cimmeria, and East Huygens crater for the Noachian epoch, in reference to their age formation (Table 1). For each epoch, the median valley depth is statistically well constrained for Strahler order $\leq 4$, because of the large number of valleys in each basin in all regions (table 6). Again, this is not really significant for the Strahler orders of 5 whose only two valleys are identified in Noachian valley networks corresponding to the main tributary of Warrego Vallis (Figure 7d) and widespread valley network of SW Newcomb crater (Figure 5d), which both debouch into terminal plains. Except this gap to

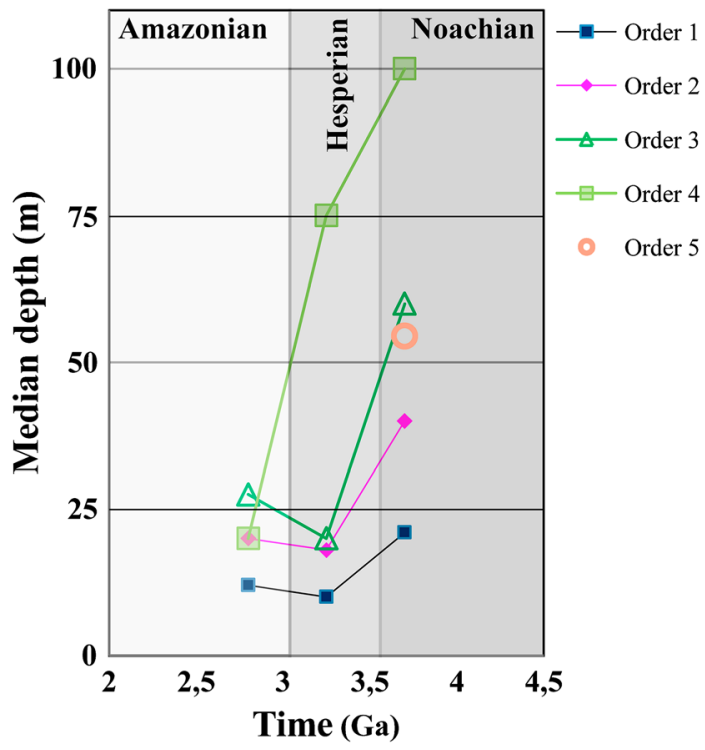

Figure 14. Evolution of median valley depth for each Strahler order (see the text for explanation). The median valley depth is defined from depth of the total number of valleys for each order belonging to the same epoch of time. Amazonian: Alba Patera. Hesperian: Echus Plateau and Holden/Eberswalde crater. Noachian: Thaumasia highlands, Tyrrhena Terra, SW Newcomb crater, Terra Cimmeria, and East Huygens crater. Only two valleys have a Strahler order of 5 in Noachian epoch, corresponding to main tributary of Warrego Vallis and widespread valley network of SW Newcomb crater. 
Table 6. Median Valley Depth (m) for Each Strahler Order in Each Epoch of Time ${ }^{\mathrm{a}}$

\begin{tabular}{lcccccccccccccccccccc}
\hline & Order 1 & $\mathrm{nb}$ & $-\sigma \mathrm{h}$ & $+\sigma \mathrm{h}$ & Order 2 & $\mathrm{nb}$ & $-\sigma \mathrm{h}$ & $+\sigma \mathrm{h}$ & Order 3 & $\mathrm{nb}$ & $-\sigma \mathrm{h}$ & $+\sigma \mathrm{h}$ & Order 4 & $\mathrm{nb}$ & $-\sigma \mathrm{h}$ & $+\sigma \mathrm{h}$ & Order 5 & $\mathrm{nb}$ & $-\sigma \mathrm{h}$ & $+\sigma \mathrm{h}$ \\
\hline Amazonian & 12.0 & 138 & 5.0 & 8.0 & 20.0 & 30 & 4.5 & 5.0 & 27.5 & 12 & 8.0 & 7.5 & 20.0 & 2 & 5.0 & 5.0 & & & \\
Hesperian & 10.0 & 116 & 5.0 & 15.0 & 18.0 & 33 & 8.0 & 9.0 & 20.0 & 10 & 5.8 & 30.0 & 75.0 & 2 & 15.0 & 15.0 & & \\
Noachian & 21.0 & 1029 & 11.0 & 19.0 & 40.0 & 263 & 15.0 & 20.0 & 60.0 & 76 & 22.5 & 30.0 & 100.0 & 13 & 30.0 & 35.0 & 54.5 & 2 & 9.8 & 9.8 \\
\hline
\end{tabular}

${ }^{a}$ Amazonian: Alba Patera. Hesperian: Echus Plateau and Holden/Eberswalde crater and Noachian: Thaumasia highlands, Tyrrhena Terra, SW Newcomb crater, Terra Cimmeria and East Huygens crater. " $\sigma \mathrm{h}$ " corresponds to the difference in depth between the median and the first quartile, and the third quartile. "nb" corresponds to the number of valleys used in epoch of time.

the tendency of an increase in depth with a higher Strahler order for valleys debouching into plains, valley networks usually follow this tendency whatever their age (Figure 14). This tendency is more pronounced for Noachian valley networks for which depth is systematically $\sim 1.5$ times higher than those measured in younger valley networks.

[49] In summary, the main results from the measurement of valley depths are: (A) Valley depths increase with Strahler orders for all valleys (Figure 13), which is a compelling evidence for erosional processes following topography for all the networks studied; (B) older valleys are deeper than younger ones from one Strahler order to another (Figures 13 and 14 and relation (1)), indicating that older networks experienced pronounced and prolonged erosion.

\section{Summary and Discussion}

\subsection{Implications of the Morphometry for Erosional Processes}

[50] Our observations and measurements show several results demonstrating that the erosion of valley networks was achieved by erosional processes involving precipitation, i.e., rainfall or snow deposition and subsequent melting. Indeed, several parameters demonstrate that the valley networks studied are geometrically similar to those of current terrestrial rivers. First, Hack's law performed on 13 of the largest basins shows a Hack exponent of $0.64(+0.14 /$ -0.17 ) in agreement with values found on Earth (Figure 11 and Table 4). Second, the relationship between the increase in valley depth and increasing Strahler order for almost all basins studied (perhaps with exception of Holden/Eberswalde) is typical of the gradual erosion by rivers from multiple heads to a single outlet. Third, bifurcation and length ratios are also consistent with values found on Earth (Table 3).

[51] The relationship between valley depth and order, and the Hack exponent also support the concept that valleys were incised throughout the whole watershed during the same period, and that erosion occurred efficiently throughout widespread area. In contrast, erosional activity scattered in time and location would have generated large inconsistencies in these geometric parameters.

[52] The average drainage density, extracted from HRSC DEMs at $\sim 1: 245,000$ scale (i.e., resolution of $\sim 75 \mathrm{~m}$.pixel ${ }^{-1}$ ) is $\sim 0.15 \mathrm{~km}^{-1}$, an order of magnitude higher than measured from MOLA and IR daytime THEMIS images [e.g., Luo and Stepinski, 2006; Hynek et al., 2010]. Although our drainage densities remain low in comparison to terrestrial ones (i.e., $5-100 \mathrm{~km}^{-1}$ usually measured from maps with scales ranging from 1:20,000 and 1:100,000 [Carr and Chuang, 1997], in semiarid regions), they are very close to terrestrial ones measured in the driest areas of the Texas state from the database of the hydrologic regions and flow lines of the United States at scale of 1:100,000 (i.e., $<0.2 \mathrm{~km}^{-1}$ [Smith et al., 2013]). Our values indicate that precipitation and surface runoff were required on Mars for incising valley networks. In addition, drainage densities suggest that Martian climate conditions could range from arid to semiarid zones, as measured in different states of America, such as Texas and Arizona, in which precipitation is $<500 \mathrm{~mm} . \mathrm{yr}^{-1}$ [NOAA, 2000; Smith et al., 2013].

[53] While this study was not designed to derive morphological interpretation from images, the combination of images and 3D can be useful. An advantage of the HRSC data is that they provide a $3 \mathrm{D}$ view (with the image at full scale).

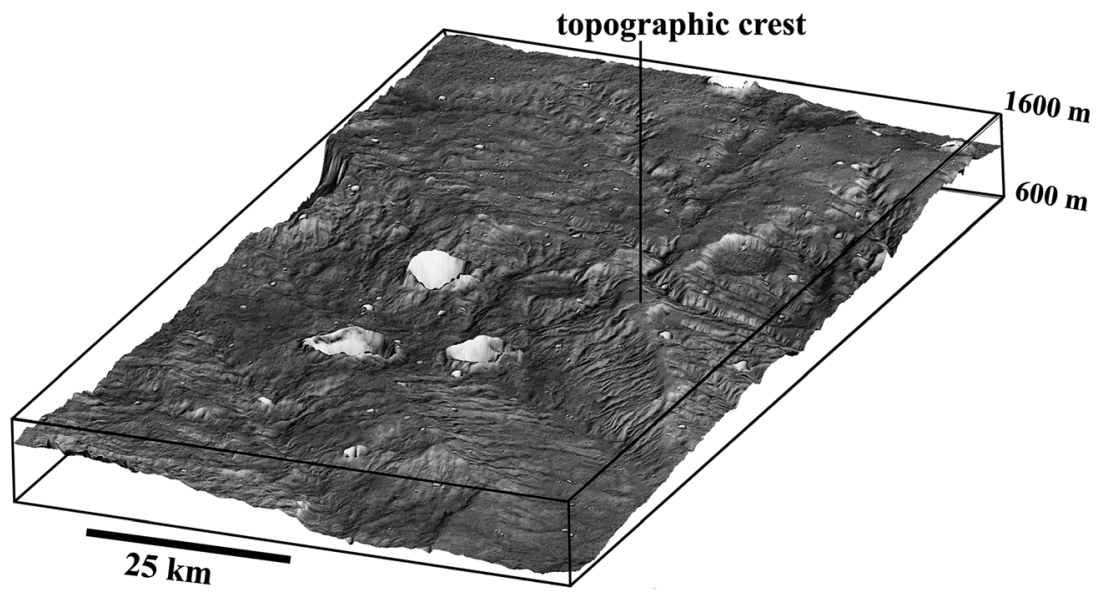

Figure 15. 3D view of very dense valley networks in SW area of Newcomb ejecta. Note that the valleys incised symmetrically hillslopes which is consistent with fluvial erosion by rainfall/snowfall and subsequent melting. 

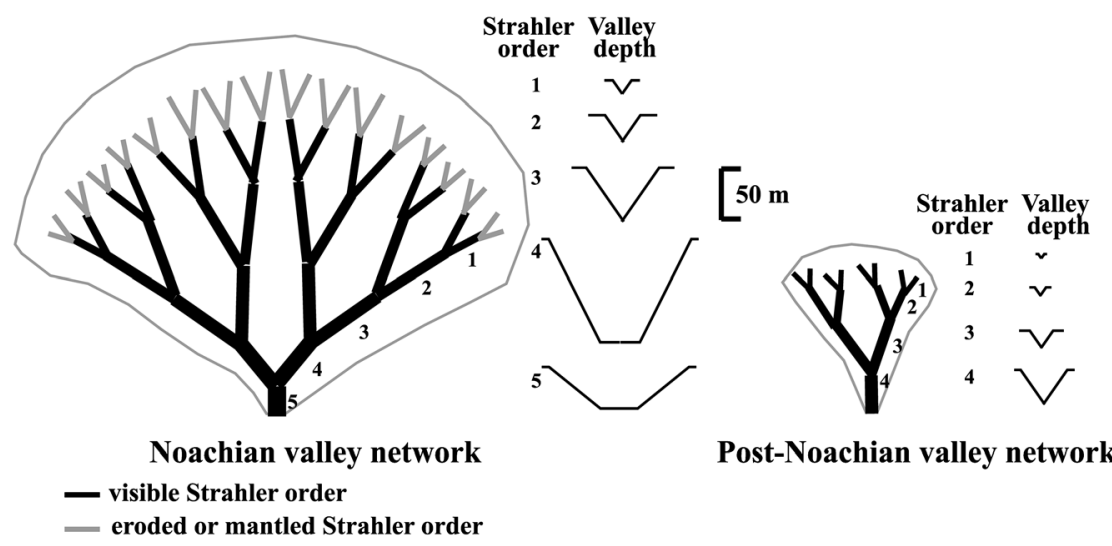

Post-Noachian valley network

Figure 16. Comparative sketch of valley networks in $2 \mathrm{D}$ plan view and valley depth versus Strahler order in the Noachian and Post-Noachian epochs.

As an example (Figure 15), the region of Newcomb crater shows a great number of valleys incising two opposite hillslopes with the same organization as that observed in terrestrial mountains. Other examples show similar divides between two opposite-facing drainage basins in regions of Huygens crater and Echus Plateau. Such geometry is also in agreement with precipitation and overland flows [Craddock and Howard, 2002; Mangold et al., 2004; Irwin et al., 2005a, 2005b; Ansan et al., 2008].

[54] From analysis of images and DEMs, several previous studies suggested that Martian valleys are not similar to terrestrial ones and that they did not require precipitation. Instead, they argued for sapping from local discharges in relation with the melting of permafrost induced by higher geothermal flux in a dry and cold climate [Gulick, 1998; Tanaka et al., 1998; Dohm and Tanaka, 1999; Goldspiel and Squyres, 2000]. However, most of these studies focused on large and deep valleys rather than valley networks. For example, Som et al. [2009] found Hack parameters inconsistent with terrestrial valleys (up to 19.2, much larger than the value of 0.6). However, most of the 10 basins used for their measurements are large and flat valleys that are poorly branching, such as Nanedi or Nirgal Valles, and three of them are either outflow channels or volcanic channels (Hrad Vallis, Tinto Vallis, Bahram Vallis). None of their "valleys" are dense valley networks at all. Their result cannot be thus extrapolated for all valleys on Mars.

[55] In summary, results from parameters such as Hack's law, bifurcation ratio, and the increase in depth with Strahler orders all converge to the point that valley networks were achieved by erosional processes involving precipitations.

\subsection{Implications for Fluvial Activity Through Time and Relations With Climate}

[56] Several morphometric parameters are not distinct from one age class to another. On one hand, the similarity in Hack exponent and bifurcation ratio/length ratio is a consequence that valleys are related to precipitation even the youngest. These parameters do not allow us to discriminate between changes in intensity, in the process, or the duration of erosion. On the other hand, parameters such as drainage densities and Strahler orders could be indicative of a valley evolution over time, but only if the networks are not fully developed. Indeed, dendritic patterns usually require $>1000$ years (in weak lithology) to develop to the point where the network has a large number of tributaries and a dense drainage density [Schumm, 1956; Schumm et al., 1987; Knighton, 1998]. After the network has reached their maximum density, we cannot deduce the duration of subsequent fluvial activity. Actually, the drainage density in younger basins is higher than oldest ones. This is true in our data set using 3D data, and even more true using visible images. The reason is that the youngest valleys are preserved and display some very small tributaries while the smallest tributaries of Noachian valleys may not be preserved (Figure 16), because of aeolian and volcanic resurfacing and impact cratering.

[57] In contrast, 3D parameters reveal a clear evolution through time (Figure 15). Older valleys are $\sim 3$ times deeper than younger ones (Figures 12 and 13), demonstrating a much stronger erosion of bedrock. Older valleys also show a higher gradient of incision from one Strahler order to another (Figures 13 and 14 and relation (1)). These older networks experienced either a higher intensity of fluvial erosion or longer duration of erosion, or both. It is not possible to discriminate between these hypotheses from available orbital data. Our results confirm the overall idea that Noachian valleys developed from more intense period of erosion in agreement with some previous studies [e.g., Craddock and Maxwell, 1993; Craddock and Howard, 2002; Ansan and Mangold, 2006; Ansan et al., 2008; Hynek et al., 2010]. Although this scenario is contested by previous climatic models concluding that early Mars surface was dry and cold [Kasting, 1991; Clifford, 1993; Fastook et al., 2012], especially due to the lower insolation of the faint sun [Gough, 1981], the 2D geometry, distribution, and depth of these valleys show parameters consistent with enhanced fluvial activity in this period compared to the more recent ones.

[58] The last point to discuss is the geographic location of valleys networks and their implication for the Martian climate evolution. The widespread distribution of Noachian valley networks is interpreted as result of a fluvial activity in a globally warmer and wetter climate [e.g., Howard et al., 2005; Irwin et al., 2005a; Fassett and Head, 2008]. In contrast, younger valley networks are sparsely localized on small areas, high plateaus or volcanoes, suggesting that they could have formed by transient wet climatic episodes and/or regional activity (e.g., water ice sources, impact crater, or volcanic activity favoring melting of ice/snow), 
occurring in relatively dry and cold climate compared to the Noachian, in agreement with several previous studies [e.g., Fassett and Head, 2008; Mangold, 2012].

[59] In summary, our study shows a decrease in fluvial activity expressed in the landscape by a factor of 3 onto the valley depth between Noachian and some of the most developed late stage valleys. This likely reflects a drying of the Martian climate; however, we do not have sufficient evidence to determine if the transition from wet to dry climate conditions was abrupt or continuous. Questions remain about the duration and the absolute intensity of fluvial erosion during different epochs of Mars. Answers to questions require a better knowledge of lithology, hydrology, and eroded volumes for improving the implications in terms of climatic conditions.

\subsection{Limitations From the Lithology}

[60] Most of valley networks are capped by sand and dust mantle, preventing the identification of rocks (chemical composition, texture, and structure) in which they were formed. Despite mantling, it is possible to infer that most of the subsurface probably consists of regolith, volcanic material, and impact debris due to impact cratering, as observed in scattered locations from both landers [Squyres et al., 2004] and orbital data [Bandfield, 2002; Bibring et al., 2005]. Fractured, brecciated materials would have been thus a good terrain on which runoff would have incised valleys. Volcanic materials could be lava flows, tephra, and ash deposits, as those observed in fine-scale layers by the Spirit MER [Squyres et al., 2007]. The surface runoff is usually quite efficient in volcanic friable, grain-sized materials overlying lava flows on Earth [Gulick and Baker, 1990; Craddock et al., 2012], which could occur in volcanic region on Mars, such as Alba Patera. In contrast, surface runoff is rather inefficient on terrestrial volcanic flows or trap region in which groundwater flow is dominant due to high connection of fractures formed during lava cooling and lava tubes. In this type of volcanic regions, poorly branched valley networks develop with deep valleys, as the Columbia River, in Washington State, U.S.A. This organization could correspond to long and deep valleys on Mars, such as Nanedi and Nirgal Vallis, which suggests that they would be formed in volcanic trap areas.

[61] Some of the previous interpretations could be limited by the lithology if the latter is variable from one region to another. For example, if late stage valleys formed on stronger terrains, the erosion could be slower. Actually, the bedrock of Noachian regions is likely composed of fractured crustal bedrock much more resistant to erosion than volcanic ash/ tephra, sedimentary deposits, and crater ejecta, respectively, present at Alba Patera [Gulick and Baker, 1990], Echus Plateau [Mangold et al., 2004, 2008)], and Holden/ Eberswalde region [Mangold et al., 2012a]. So, this weaker lithology for younger valleys suggests that they formed during an even much shorter timescale and lower intensity of fluvial erosion than Noachian ones, in agreement with the conclusions from the section 4.2.

[62] The Hack exponents measured are consistent with terrestrial data and show that the distribution of valleys inside basins is relatively self-similar whatever the area of subbasins. As drainage density, the self-similar organization of valleys throughout watersheds reflects the spacing of tributaries, the interaction between climate and geology, and the lithology, on Earth. The latter is crucial in erosion processes which are controlled both by chemical and physical properties of materials (e.g., chemical dissolution, texture of material (grain size), mechanic resistance of surface material to the erosion (shear stress), infiltration capacity...) and structure of material (e.g., layered and/or fractured material). For small terrestrial basins, the self-similar distribution of valleys is controlled by a homogeneous lithology and a low infiltration capacity or permeability of soil [Carlson, 1963; Patton, and Baker, 1976; Ritter et al., 2002].

[63] In addition, orbital data provide evidence of sedimentary layered deposits [e.g., Malin and Edgett, 2000] as deduced by their composition (e.g., sulfate, phyllosilicates or clays [Bibring et al., 2005; Gendrin et al., 2005; Poulet et al., 2005; Loizeau et al., 2007]) and structure (e.g., lacustrine and deltaic deposits [Malin and Edgett, 2003; Pondrelli et al., 2005; Lewis and Aharonson, 2006; Ansan et al., 2011]). At present, no observation shows a systematic relationship between erosion zones (valley network) and deposit zones (alluvial and deltaic deposit), except in Eberswalde crater, because of resurfacing by both aeolian and volcanic activity. But, we can infer a change in lithology by a change in valley geometry and pattern. Vichada Valles is a good example, in which long and deep valleys are present in the northern part of watershed, suggesting the presence of a volcanic plateau substratum. The southern part of Vichada Valles is characterized by networks of numerous, small and shallow valleys that debouched into layered terrains filling Hellas basin, which are interpreted as a mixture of volcanic and sedimentary deposits [e.g., Moore and Wilhelms, 2001; Mest et al., 2010]. Identifying the lithology in which valley networks formed is a future challenge for better understanding past fluvial activity on Mars.

\subsection{Improvement of Morphometry Analysis Using HRSC DEMS}

[64] Mapping of valley networks has been greatly improved by the high resolution of HRSC images and DEMs covering widespread areas. In numerous cases, the HRSC DEM gridding is four times greater than that of MOLA. However, the quality of the HRSC DEMs strongly depends on the acquisition geometry of the triplet of images, which controls the spatial resolution, the image quality (compression ratio, aerosols, etc.), and the surface roughness [Jaumann et al., 2007; Ansan et al., 2008]. The surface roughness is a crucial parameter because the stereogrammetry method is based on the recognition of homologous points. This method is important when the surface is hilly and rough, which is very good for detecting valley depths. In contrast, when the surface is smooth, such as in plains, the total number of homologous points drops drastically, preventing a detailed topographic analysis. As the valley networks studied here are located in relatively hilly terrains, except in south part of Tyrrhena Terra incised by Vichada Valles, the surface roughness is not a problem.

[65] Because of the high spatial resolution of HRSC DEMs, the automatic detection of valley networks has been greatly improved compared to those extracted from the MOLA grid. The drainage divides are also better defined. The number of subbasins is higher with a smaller watershed surface (e.g., in Echus Plateau, the mean surface of watershed 
is $\sim 390 \mathrm{~km}^{2}$ in MOLA whereas it is $\sim 100 \mathrm{~km}^{2}$ in HRSC DEM for 45 basins detected [Ansan et al., 2008]). The number of valleys is also significantly higher than found in MOLA, leading to an increase in the derived drainage density by a factor of 2 , reaching $0.22 \mathrm{~km}^{-1}$ for valley networks having a Strahler order $\geq 3$ (Table 4), compared to those of earlier studies from MOLA in the same basins [Ansan et al., 2008]. The HRSC DEMs show accurate information on small tributaries width and depth, permitting to detect shallow and narrow valleys, typically $<20 \mathrm{~m}$ in depth and $<1 \mathrm{~km}$ in width. Last, Hack's law was used at a degree of precision necessary by taking into account small basins that may not be accurate at MOLA scale.

\section{Conclusions}

[66] Eight dense branching valley networks were studied in Noachian terrains of Huygens, Newcomb and Kepler craters, south Tyrrhena Terra and Thaumasia, in Hesperian terrains of Echus Plateau and west Eberswalde craters, and in Amazonian terrains of Alba Patera, using images and digital elevation models (DEMs) from the Mars Express High Resolution Stereo Camera (HRSC) to determine 2D and 3D morphometric parameters. This topographic data set, with good spatial coverage and sufficient image resolution, significantly improves measurements previously done at MOLA scale. Results show (Figure 16):

[67] 1. Martian valley networks reflect 2D branching pattern of terrestrial fluvial drainage systems with similar geometry and bifurcation ratios. The relatively higher drainage densities for younger valleys probably reflect the preservation of these valleys and not a more intense fluvial activity.

[68] 2. All dense branched valley networks follow the same trend for Hack's law as terrestrial river networks, i.e., Hack exponent $n$ ranging from 0.47 to 0.78 for the 13 basins, is close to value of 0.6 found on Earth. This indicates that the valley spatial distribution follows a relatively good self-similarity inside Martian watersheds. In addition, measurements of valley depths by increasing Strahler order show a progressive deepening of valleys for larger orders. Both observations argue in favor of either rainfall or snowfall with subsequent melting and a perennial water cycle with coeval activity of erosion throughout the entire watershed.

[69] 3. Post-Noachian valleys are less numerous, shallower, localized on small areas, on high plateaus, or volcanoes. However, the geometry of the few examples does show characteristics consistent with fluvial erosion, perhaps with exception of west Eberswalde, which valleys do not increase in depth as a function of Strahler order. This suggests that these valleys could form from more regional thermal anomalies or transient climatic episodes, but would still require melting of precipitated snow- or frost/ice packs.

[70] 4. Noachian valleys are more deeply incised $(\sim 100 \mathrm{~m})$ than Hesperian and Amazonian valleys (depths), including the more developed younger valleys studied here. Our study confirms the general idea that fluvial activity was more intense during the Late Noachian/Early Hesperian and decreased sharply thereafter.

[71] Acknowledgments. We acknowledge the effort of the HRSC CoInvestigator Team members and their associates who have contributed to this investigation in the preparatory phase and in scientific discussions. Authors were supported by the Programme National de Planétologie (PNP) of the
Institut National des Sciences de l'Univers (INSU) and the Centre National d'Etude Spatial (CNES). We acknowledge the constructive reviews received from Bob Craddock and an anonymous reviewer.

\section{References}

Albertz, J., et al. (2005), HRSC on Mars Express-Photogrammetric and cartographic research, Photogramm. Eng. Remote Sens., 71(10), 1153-1166.

Andrews-Hanna, J. C., and K. W. Lewis (2011), Early Mars hydrology: 2. Hydrological evolution in the Noachian and Hesperian epochs, J. Geophys. Res., 116, E02007, doi:10.1029/2010JE003709.

Ansan, V., and N. Mangold (2006), New observations of Warrego Valles. Mars: Evidence for precipitation and surface runoff, Planet. Space Sci., 54, 219-242, doi:10.1016/j.pss.2005.12.009.

Ansan, V., N. Mangold, P. Masson, E. Gailhardis, and G. Neukum (2008), Topography of valley networks on Mars from the Mars Express High Resolution Stereo Camera Digital Elevation Models, J. Geophys. Res., 113, E07006, doi:10.1029/2007JE002986.

Ansan, V., N. Mangold, P. Masson, and G. Neukum (2009), Fluvial valleys on Alba Patera, Mars, viewed by HRSC/MEx camera presented at 2009 Fall Meeting, AGU, San Francisco, USA.

Ansan, V., et al. (2011), Stratigraphy, mineralogy, and origin of layered deposits inside Terby crater, Mars, Icarus, 221, 273-304, doi:10.1016/j. icarus.2010.09.011.

Baker, V. R. (1990), Spring sapping and valley network development, In: Higgins. C.G.. Coates D.R. (Eds.). Groundwater Geomorphology: The Role of Subsurface Water in Earth-Surface Processes and Landform, Geol. Soc. Am. Bull., 252, 235-265 (Special Paper).

Baker, V. R., and R. C. Kochel (1979), Martian channel morphology: Maja and Kasei Valles, J. Geophys. Res., 84, 7961-7983.

Baker, V. R., and J. Partridge (1986), Small Martian valleys: pristine and degraded morphology, J. Geophys. Res., 91, 3561-3572, doi:10.1029/ JB091iB03p03561.

Baker, V. R., M. H. Carr, V. C. Gulick, C. R. Williams, and M. S. Marley (1992), Channels and valley networks, in Mars, edited by H. H. Kieffer, B. Jakosky, C. Snyder, and M. Matthews, pp. 493-522, University of Arizona Press, Tucson.

Bandfield, J. L. (2002), Global mineral distribution on Mars, J. Geophys. Res., 107, 5042, doi:10.1029/2001JE001510.

Bibring, J. P., et al. (2005), Mars surface diversity as revealed by the OMEGA/MarsExpress observations, Science, 307(5715), 1576-1581, doi:10.1126/science. 1108806 .

Bouley, S., V. Ansan, N. Mangold, P. Masson, G. Neukum, and the HRSC co-Investigator team (2009), Fluvial morphology of Naktong Vallis Mars: A late activity with multiple processes, Planet. Space Sci., 57, 982-999, doi:10.1016/j.pss.2009.01.015.

Bouley, S., R. A. Craddock, N. Mangold, and V. Ansan (2010), Characterization of fluvial activity in Parana Valles using different age-dating techniques, Icarus, 207, 686-698, doi:10.1016/j.icarus.2009.12.030.

Cabrol, N. A., and E. A. Grin (2001), Composition of the drainage network on early Mars, Geomorphology, 37, 269-287.

Caprarelli, G., and B. Y. Wang (2012), Wet Mars implications of revised scaling calculations for Evros Vallis, Aust. J. Earth Sci.: An Int. Geosci. J. Geol. Soc. Aust., 59(2), 263-276.

Carr, M. H. (1981), Mars, in The Geology of Terrestrial Planets, edited by M. H. Carr, pp. 207-263, NASA Special Publications, NASA SP-469.

Carr, M. H. (1995), The Martian drainage system and the origin of networks and fretted channels, J. Geophys. Res., 100, 7479-7507.

Carr, M. H. (1996), Water on Mars, edited by M. H. Carr, 229 pp., Oxford University Press, New York.

Carr, M. H., and F. C. Chuang (1997), Martian drainage densities, J. Geophys. Res., 102, 9145-9152.

Carr, M. H., and G. D. Clow (1981), Martian channels and valleys: their characteristics, distribution, and age, Icarus, 48, 91-117.

Carr, M. H., and M. C. Malin (2000), Meter-scale characteristics of Martian channels and valleys, Icarus, 146, 366-386.

Carlston, C. W. (1963), Drainage density and streamflow, U.S. Geol. Surv. Prof., Paper 422C.

Chapman, M. G., et al. (2010), Noachian-Hesperian geologic history of the Echus Chasma and Kasei Valles system on Mars: New data and interpretations, Earth Planet. Sci. Lett., 294, 256-271, doi:10.1016/j.epsl.2009.11.032.

Clifford, S. M. (1993), A model for the hydrologic and climatic behavior of water on Mars, J. Geophys. Res., 98, 10,973-11,016.

Craddock, R. A., and T. A. Maxwell (1993), Geomorphic evolution of the Martian Highlands through ancient fluvial processes, J. Geophys. Res., 98, 3453-3468.

Craddock, R. A., and A. D. Howard (2002), The case for rainfall on a warm. wet early Mars, J. Geophys. Res., 107(E11), 5111, doi:10.1029/ 2001JE001505. 
Craddock, R. A., A. D. Howard, R. P. Irwin, S. Tooth, R. M. E. Williams, and P.-S. Chu (2012), Drainage network development in the Keanakako'i tephra, Kilauea Volcano, Hawaii: Implications for fluvial erosion and valley network formation on early Mars, J. Geophys. Res., 117, E08009, doi:10.1029/2012JE004074.

Dickson, J. L., C. I. Fassett, and J. W. Head (2009), Amazonian-aged fluvial valley systems in a climatic microenvironment on Mars: Melting of ice deposits on the interior of Lyot Crater, Geophys. Res. Lett., 36, L08201, doi:10.1029/2009GL037472.

Dodds, P. S., and D. H. Rothman (2000), Scaling universality and geomorphology, Annu. Rev. Earth Planet. Sci., 28, 571-610.

Dohm, J. M., and K. L. Tanaka (1999), Geology of Thaumasia region, Mars: Plateau development, valley origins, and magmatic evolution, Planet. Space Sci., 47, 411-431.

Duxbury. T. C., R. L. Kirk, B. A. Archinal, and G. A. Neumann (2002), Mars geodesy/cartography working group recommendation on Mars cartographic constants and coordinate systems, Paper presented at Joint International Symposium on Geospatial Theory. Processing and Application, Int. Soc. for Photogramm. and Remote Sens., Ottawa. Ont.

Farmer, C. B., and P. E. Doms (1979), Global and seasonal water vapor on Mars and implications for permafrost, J. Geophys. Res., 84, 2881-2888.

Fassett, C. I., and J. W. Head (2007), Valley formation on martian volcanoes in the Hesperian: Evidence for melting of summit snowpack, caldera lake formation, drainage and erosion on Ceraunius Tholus, Icarus, 189, 118-135, doi:10.1016/j.icarus.2006.12.021.

Fassett, C. I., and J. W. Head (2008), The timing of Martian valley network activity: Constraints from buffered crater counting, Icarus, 195, 61-89, doi:10.1016/j.icarus.2007.12.009.

Fassett, C. I., J. L. Dickson, J. W. Head, J. S. Levy, and D. R. Marchant (2010), Supraglacial and proglacial valleys on Amazonian Mars, Icarus, 208, 86-100, doi:10.1016/j.icarus.2010.02.021.

Fastook, J. L., J. W. Head, D. R. Marchant, F. Forget, and J. B. Madeleine (2012), Early Mars climate near the Noachian-Hesperian boundary: Independent evidence for cold conditions from basal melting of the south polar ice sheet (Dorsa Argentea Formation) and implications for valley network formation, Icarus, 219, 25-40, doi:10.1016/j.icarus.2012.02.013.

Forget, F., and R. T. Pierrehumbert (1997), Warming early Mars with carbon dioxide clouds that scattered infrared radiation, Science, 278, 1273-1276.

Gendrin, A., et al. (2005), Sulfates in Martian layered terrains: The OMEGA/ Mars Express view, Science, 307, 1587-1591, doi:10.1126/science.1109087.

Goldspiel, J. M., and S. W. Squyres (2000), Groundwater sapping and valley formation on Mars, Icarus, 148, 176-192.

Gough, D. O. (1981), Solar interior structure and luminosity variations, Sol. Phys., 74, 21-34.

Grant, J. A. (2000), Valley formation in Margaritifer Sinus. Mars. by precipitation-recharged ground-water sapping, Geology, 28, 223-226.

Grant, J. A., and S. A. Wilson (2011), Late alluvial fan formation in southern Margaritifer terra, Mars, Geophys. Res. Lett., 38, L08201, doi:10.1029/ 2011 GL046844.

Greeley, R., and J. J. Guest (1987), Geologic map of the eastern equatorial region of Mars, scale 1:15.000.000, U.S. Geol. Surv. Map. I-1802-B.

Gulick, V. C. (1998), Magmatic intrusions and hydrothermal origin for fluvial valleys on Mars, J. Geophys. Res., 103, 19,365-19,387.

Gulick, V. C. (2001), Origin of the valley networks on Mars: A hydrological perspective, Geomorphology, 37, 241-268.

Gulick, V. C., and V. R. Baker (1989), Fluvial valleys and Martian paleoclimates, Nature, 341, 514-516.

Gulick, V. C., and V. R. Baker (1990), Origin and evolution of valleys on Martian volcanoes, J. Geophys. Res., 95, 14,325-14,344.

Gwinner, K., F. Scholten, R. Jaumann, T. Roatsch, J. Oberst, and G. Neukum (2007), Global mapping of Mars by systematic derivation ofMars Express HRSC high-resolution digital elevation models and orthoimages, Paper presented at Extraterrestrial Mapping Workshop on Advances in Planetary Mapping 2007, ISPRS Comm. IV, Working Group 9. Houston. Tex.

Hack, J. T. (1957), Studies of longitudinal stream profiles in Virginia and Maryland, USGS Prof. Pap., 294-B, 45-97.

Harrison, K. P., and R. E. Grimm (2008), Multiple flooding events in Martian outflow channels, J. Geophys. Res., 113, E02002, doi:10.1029/ 2007JE002951.

Hartmann, W. K. (2005), Martian cratering: 8 Isochron refinement and the history of Martian geologic activity, Icarus, 174, 294-320, doi:10.1016/ j.icarus.2004.11.023.

Hartmann, W. K., and G. Neukum (2001), Cratering chronology and the evolution of Mars, Space Sci. Rev., 96, 165-194, doi:10.1023/ A:1011945222010.

Hauber, E., et al. (2005), Discovery of a flank caldera and very young glacial activity at Hecates Tholus Mars, Nature, 434, 356-361.

Hauber, E., K. Gwinner, M. Kleinhans, D. Reiss, G. Di Achille, G. G. Ori, F. Scholten, L. Marinangeli, R. Jaumann, and G. Neukum (2009),
Sedimentary deposits in Xanthe Terra: Implications for the ancient climate on Mars, Planet. Space Sci., 57, 944-957, doi:10.1016/j.pss.2008.06.009.

Horton, R. E. (1945), Erosional development of streams and their drainage basin, Hydrophysical approach to quantitative morphometry, Geol. Soc. Am. Bull., 56, 275-370.

Howard, A. D. (1988), Sapping features of the Colorado Plateau, in $A$ Comparative Planetary Geology Field Guide, edited by A. D. Howard, R. C. Kochel, and H. E. Holt, NASA SP-491, 108.

Howard, A. D., J. M. Moore, and R. P. Irwin (2005), An intense terminal epoch of widespread fluvial activity on early Mars: 1 . Valley network incision and associated deposits, J. Geophys. Res., 110, E12S14, doi:10.1029/2005JE002459.

Hynek, B. M., M. Beach, and M. R. T. Hoke (2010), Updated global map of Martian valley networks and implications for climate and hydrologic processes, J. Geophys. Res., 115, E09008, doi:10.1029/2009JE003548.

Ijjasz-Vasquez, E. J., R. L. Bras, and I. Rodriguez-Iturbe (1993), Hack's relation and optimal channel networks: The elongation of river basin as a consequence of energy minimization, Geophys. Res. Lett., 20(15), $1583-1586$.

Irwin, R. P., and A. D. Howard (2002), Drainage basin evolution in Noachian Terra Cimmeria. Mars, J. Geophys. Res., 107(E7), 5056, doi:10.1029/2001JE001818.

Irwin, R. P., R. A. Craddock, and A. D. Howard (2005a), Interior channels in Martian valley networks: Discharge and runoff production, Geology, 33(6), 489-492, doi:10.1130/G21333.1.

Irwin, R. P., A. D. Howard, R. A. Craddock, and J. M. Moore (2005b), An intense terminal epoch of widespread fluvial activity on early Mars: 2 . Increased runoff and paleolake development, J. Geophys. Res., 110, E12S15, doi:10.1029/2005JE002460.

Irwin, R. P., A. D. Howard, and R. A. Craddock (2008), Fluvial valleynetworks on Mars, in River confluences, tributaries and the fluvial network, edited by S. P. Rice, A. G. Roy, and B. L. Rhoads, pp. 419-451, Wiley, Chichester, U. K.

Ivanov, M. A., and J. W. Head (2006), Alba Patera, Mars: Topography, structure, and evolution of a unique late Hesperian-early Amazonian shield volcano, J. Geophys. Res., 111, E09003, doi:10.1029/ 2005JE002469.

Jaumann, R., et al. (2005), Interior channels in Martian valleys: Constraints on fluvial erosion by measurements of the Mars Express High Resolution Stereo Camera, Geophys. Res. Lett., 32, L16203, doi:10.1029/ 2005 GL023415.

Jaumann, R., et al. (2007), The high resolution stereo camera (HRSC) experiment on Mars express: Instrument aspects and experiment conduct from interplanetary cruise through the nominal mission, Planet. Space Sci., 55, 928-952, doi:10.1016/j.pss.2006.12.003.

Kasting, J. F. (1991), CO2 condensation and the climate of early Mars, Icarus, 94, 1-13.

Kleinhans, M. G. (2005), Flow discharge and sediment transport models for estimating a minimum timescale of hydrological activity and channel and delta formation on Mars, J. Geophys. Res., 110, E12003, doi:10.1029/ 2005JE002521.

Kleinhans, M. G., H. E. van de Kasteele, and E. Hauber (2010), Palaeoflow reconstruction from fan delta morphology on Mars, Earth Planet. Sci. Lett., 294, 378-392, doi:10.1016/j.eps1.2009.11.025.

Knighton, D. (1998), Fluvial Forms and Processes: A New Perspective, 383 pp., Oxford Univ, Press, New York.

Kraal, E. R., et al. (2008), Martian stepped-delta formation by rapid water release, Nature, 451, 973-U2, doi:10.1038/nature06615.

Leighton, R. B., B. C. Murray, R. P. Sharp, J. D. Allen, and R. K. Sloan (1965), Mariner IV photography of Mars: initial results, Science, 149, 627-630.

Lewis, K. W., and O. Aharonson (2006), Stratigraphic analysis of the distributary fan in Eberswalde crater using Stereo imagery, J. Geophys. Res., 111, E06001, doi:10.1029/2005JE002558.

Loizeau, D., et al. (2007), Phyllosilicates in the Mawrth vallis region of Mars, J. Geophys. Res., 112, E08S08, doi:10.1029/2006JE002877.

Luo, W. (2002), Hypsometric analysis of Margaritifer Sinus and origin of valley networks, J. Geophys. Res., 107(E10), 5071, doi:10.1029/ 2001JE001500.

Luo, W., and T. F. Stepinski (2006), Topographycally derived maps of valley networks and drainage density in the mare Tyrrhenum quadrangle of Mars, Geophys. Res. Lett., 33, L18202, doi:10.1029/2006GL027346.

Malin, M. C., and M. H. Carr (1999), Groundwater formation of Martian valleys, Nature, 397, 589-591.

Malin, M. C., and K. S. Edgett (2000), Evidence for recent groundwater seepage and surface runoff on Mars, Science, 288, 2330-2335.

Malin, M. C., and K. S. Edgett (2003), Evidence for persistent flow and aqueous sedimentation on early Mars, Science, 302, 1931-1934, doi:10.1126/science.1090544

Mandelbrot, B. B. (1983), The fractal geometry of nature, 468 pp., W.H. Freeman, New York. 


\section{ANSAN AND MANGOLD: MORPHOMETRY OF VALLEY NETWORKS ON MARS}

Mangold, N. (2012), Fluvial landforms on fresh impact ejecta on Mars, Planet. Space Sci., 62, 69-85, doi:10.1016/j.pss.2011.12.009.

Mangold, N., and V. Ansan (2006), Detailed study of an hydrological system of valleys. a delta and lakes in the Southwest Thaumasia region. Mars, Icarus, 180, 75-87, doi:10.1016/j.icarus.2005.08.017.

Mangold, N., C. Quantin, V. Ansan, C. Delacourt, and P. Allemand (2004), Evidence for precipitation on Mars from dendritic valleys in the Valles Marineris area, Science, 305, 78-81, doi:10.1126/science.1097549.

Mangold, N., V. Ansan, P. Masson, C. Quantin, and G. Neukum (2008), Geomorphic study of fluvial landforms of northern Valles Marineris plateau, Mars, using HRSC/MEX images and topography, J. Geophys. Res., 113, E08009, doi:10.1029/2007JE002985.

Mangold, N., E. S. Kite, M. G. Kleinhans, H. Newsom, V. Ansan, E. Hauber, E. Kraal, C. Quantin, and K. Tanaka (2012a), The origin and timing of fluvial activity at Eberswalde crater, Mars, Icarus, 220, 530-551, doi:10.1016/j.icarus.2012.05.026.

Mangold, N., S. Adeli, S. Conway, V. Ansan, and B. Langlais (2012b), A chronology of early Mars climatic evolution from impact crater degradation, J. Geophys. Res., 117, E04003, doi:10.1029/2011JE004005.

Mars Channel Working Group (1983), Channels and valleys on Mars, Geol. Soc. Am. Bull., 94, 1035-1054.

Mest, S. C., D. A. Crown, and W. Harbert (2010), Watershed modeling in the Tyrrhena Terra region of Mars, J. Geophys. Res., 115, E09001, doi:10.1029/2009JE003429.

Milton, D. J. (1973), Water and processes of degradation in the Martian landscape, J. Geophys. Res., 78, 4037-4047.

Moore, J. M., and D. E. Wilhelms (2001), Hellas as a possible site of ancient icecovered lakes on Mars, Icarus, 154, 258-276, doi:10.1006/icar.2001.6736.

Neukum, G., R. Jaumann, and the HRSC Co-Investigator Team (2004), HRSC: The high resolution stereo camera of Mars Express, Eur. Space Agency Spec. Publ. ESA., SP-1240, 17-36.

NOAA, National Climatic Data Center (2000), Climate atlas of the United States, Cd-ROM, http://www.ncdc.noaa.gov/oa/about/cdrom/climatls2/ info/atlasad.html.

O’Callaghan, J. F., and D. M. Mark (1984), The extraction of drainage networks from digital elevation data, Comput. Vision Graphics Image Process., 28, 328-344.

Patton, P. C., and V. R. Baker (1976), Morphometry and floods in small drainage basins subject to diverse hydrogeomorphic controls, Water Resour. Res., 12, 941-952.

Pieri, D. C. (1976), Martian channels: distribution of small channels on the Martian surface, Icarus, 27, 25-50.

Pieri, D. C. (1980), Martian valleys: Morphology. distribution. age and origin, Science, 210, 895-897.

Pondrelli, M., A. Baliva, S. Di Lorenzo, L. Marinangeli, and A. P. Rossi (2005), Complex evolution of paleolacustrine systems on Mars: An example from the Holden crater, J. Geophys. Res., 110, E12S19, doi:10.1029/ 2004JE002335.

Poulet, F., J.-P. Bibring, J. F. Mustard, A. Gendrin, N. Mangold, Y. Langevin, R. E. Arvidson, B. Gondet, and C. Gomez (2005), Phyllosilicates on Mars and implications for early Martian climate, Nature, 438, 623-627, doi:10.1038/nature04274.

Quantin, C., P. Allemand, N. Mangold, G. Dromart, and C. Delacourt (2005), Fluvial and lacustrine activity on layered deposits in Melas Chasma, Valles Marineris, Mars, J. Geophys. Res., 110, E12S19, doi:10.1029/2005JE002440.

Rigon, R., I. Rodriguez-Iturbe, A. Maritan, A. Gioacometti, D. G. Tarboton, and A. Rinaldo (1996), On Hack's law, Water Resour. Res., 32(11), 3367-3374.

Ritter, D. L., R. C. Kochel, and J. R. Miller (2002), Process Geomorphology, ed., 560 pp., McGraw-Hill, Boston.

Sagan, C., O. B. Toon, and P. J. Gierasch (1973), Climatic change on Mars, Science, 181, 1045-1049.

Scholten, F., K. Gwinner, T. Roasch, K.-D. Matz, M. Wahlisch, B. Giese, J. Oberst, R. Jaumann, G. Neukum, and the HRSC Co-Investigator Team (2005), Mars express HRSC data processing, Photogramm. Eng. Remote Sens., 71(10), 1143-1152.

Schumm, S. A. (1956), Evolution of drainage systems and slopes in badlands at Perth Amboy, New Jersey, Geol. Soc. Am. Bull., 67, 597-646.
Schumm, S. A., M. P. Mosley, and W. E. Weaver (1987), Experimental Fluvial Geomorphology, p. 413, John Wiley and Sons, New York.

Scott, H. S., K. L. Tanaka, R. Greeley, and J. E. Guest (1986), Geologic maps of the western equatorial. eastern equatorial and polar regions of Mars. scale 1:15.000.000. U.S. Geol. Surv. Map. I-1802-A. B and C.

Seidelmann, P. K., et al. (2002), Report of the IAU/IAG working group on cartographic coordinates and rotational elements of the planets and satellites: 2000, Celestial Mech Dyn. Astron., 82, 83-110, doi:10.1023/ A:1013939327465

Sharp, R. P., and M. C. Malin (1975), Channels on Mars, Geol. Soc. Am. Bull., 86, 593-609.

Shreve, R. L. (1966), Statistical law of stream numbers, J. Geol., 74, 17-37.

Smith, D. E. (1999), The gravity field of Mars: results from Mars Global Surveyor, Science, 286, 94-97, doi:10.1126/science.286.5437.94.

Smith, D. E., et al. (1999), The global topography of Mars and implications for surface evolution, Science, 284, 1495-1503, doi:10.1126/ science.284.5419.1495.

Smith, V. B., C. H. David, M. B. Cardenas, and Z.-L. Yang (2013), Climate, river network, and vegetation cover relationships across a climate gradient and their potential for predicting effects of decadalscale climate change, J. Hydrol., 488, 101-109, doi:10.1016/j. jhydrol.2013.02.050.

Som, S. M., D. R. Montgomery, and H. M. Greenberg (2009), Scaling relations for large martian valleys, J. Geophys. Res., 114, E02005, doi:10.1029/2008JE003132.

Squyres, S. W. (1989), Urey price lecture: water on Mars, Icarus, 79, 229-288.

Squyres, S. W., et al. (2004), The Spirit Rover's Athena Science Investigation at Gusev Crater Mars, Science, 305, 794-799, doi:10.1126/science.3050794.

Squyres, S. W., et al. (2007), Pyroclastic activity at Home Plate in Gusev Crater Mars, Science, 316, 738-742, doi:10.1126/science.1139045.

Stepinski, T. F., and M. L. Collier (2004), Extraction of Martian valley networks from digital topography, J. Geophys. Res., 109, E11005, doi:10.1029/2004JE002269.

Stepinski, T. F., and A. P. Stepinski (2005), Morphology of drainage basins as an indicator of climate on early Mars, J. Geophys. Res., 110, E12S12, doi:10.1029/2005JE002448.

Strahler, A. N. (1952), Dynamic basis of geomorphology, Geol. Soc. Am. Bull., 63, 923-938.

Strahler, A. N. (1968), Quantitative geomorphology, in Encyclopaedia of Geomorphology, edited by R. W. Fairbridge, pp. 898-912, Reinhold, New York.

Tanaka, K. L. (1986), The stratigraphy of Mars, Proc. Lunar Planet. Sci. Conf. 17th. Part 1, J. Geophys. Res., 91, E139-E158, doi:10.1029/ JB091iB13p0E139.

Tanaka, K. L., J. M. Dohm, J. H. Lias, and T. M. Hare (1998), Erosional valleys in the Thaumasia region of Mars: hydrothermal and seismic origin, J. Geophys. Res., 103, 31,407-31,420.

Tanaka, K. L., D. H. Scott, and R. Greeley (1992), Global stratigraphy, in Mars, edited by H. H. Kieffer et al., pp. 345-382, Univ. of Ariz. Press, Tucson.

Tarboton, D. G., R. L. Bras, and I. Rodriguez-Iturbe (1989), The analysis of river basins and channel networks using digital terrain data, Tech. Rep. 326, Ralf M. Parsons Lab., Mass. Inst. of Technol., Cambridge.

Tarboton, D. G., R. L. Bras, and I. Rodriguez-Iturbe (1991), On the extraction of channel networks from digital elevation data, Hydrol. Processes, 5(1), 81-100.

Toon, O. B., T. Segura, and K. Zahnle (2010), The formation of martian river Valleys by impacts, Ann. Rev. Earth Planet. Sci., 38, 303-322, doi:10.1146/annurev-earth-040809-152354.

Weitz, C. M., R. E. Milliken, J. A. Grant, A. S. McEwen, R. M. E. Williams, J. L. Bishop, and B. J. Thomson (2010), Mars Reconnaissance Orbiter observations of light-toned layered deposits and associated fluvial landforms on the plateaus adjacent to Valles Marineris, Icarus, 205, 73-102, doi:10.1016/j.icarus.2009.04.017.

Williams, R. M. E., and R. J. Phillips (2001), Morphometric measurements of Martian Valley networks from Orbiter Laser Altimeter (MOLA) data, J. Geophys. Res., 106, 23,737-23,751. 